Are young French jobseekers of ethnic immigrant origin discriminated against? A controlled experiment in the Paris area

EMMANUEL DUGUET, NOAM LEANDRI, YANNICK L'HORTY, PASCALE PETIT 
ISSN 2110-5472 


\title{
Are young French jobseekers of ethnic immigrant origin discriminated against? A controlled experiment in the Paris area
}

\author{
Emmanuel Duguet*, Noam Leandri†, \\ Yannick L'Horty ${ }^{*}$, Pascale Petit ${ }^{*}$
}

Revised, July 2009

\begin{abstract}
This study uses the findings of a correspondence testing in order to assess the potential discrimination at job access level against young people of ethnic origin from the underprivileged suburbs of the Paris area (Ile-de-France). We measure simultaneously the effects of place of residence (privileged or underprivileged city), of nationality (French or Moroccan), and of sound of surname and of forename on the chances of obtaining a job interview when answering a job ad. We base our assessment on a controlled experiment conducted on the profession of accountant. We constructed 16 jobseeker profiles and sent 1097 resumes in reply to 140 job vacancies advertised at the end of 2006. We find evidence of a significant discrimination against the candidates with a foreign origin.
\end{abstract}

Keywords : discrimination, correspondence testing

JEL classification : C81, C93, J15, J71

\begin{abstract}
Résumé
Cette étude utilise les résultats d'un test de correspondance afin d'évaluer la discrimination potentielle lors de l'accès aux entretiens d'embauche, pour les jeunes d'origine étrangère résidant dans des communes défavorisées d'Île de France. Nous mesurons simultanément les effets de la commune de résidence (ville favorisée ou défavorisée), de la nationalité (française ou marocaine) et de la consonance du nom et du prénom, sur les chances d'obtenir un entretien d'embauche en réponse à une offre d'emploi. Notre évaluation repose sur une expérience contrôlée réalisée sur la profession de comptable. Nous avons construit 16 profils de candidature et avons envoyé 1097 CV en réponse à 140 offres d'emploi postées à la fin de l'année 2006. Nous trouvons qu'il existe une discrimination significative à l'encontre des candidats d'origine étrangère.
\end{abstract}

Mots-clés : discrimination, test de correspondance.

Classement JEL : C81, C93, J15, J71

\footnotetext{
* Université d'Evry-Val d’Essonne, EPEE and CEE, 4 Bd F. Mitterrand, 91025 Evry Cedex, France (TEPP, FR CNRS 3126).

† Banque de France.
}

Acknowledgments. This research was conducted with support from the Centre d'Analyse Stratégique or "CAS" (Strategic Analysis Center). It has enjoyed oversight and remarks from Gwénaële Calvès and the members of the steering group of the CAS. We also thank the participants to the following conferences for their comments: Journées de Microéconomie Appliquée (2008, Saint-Denis de la Réunion), ECOTREND (2008, Târgu-Jiu, Romania). 


\section{Introduction}

There is a striking contrast between the increasingly large place occupied by the theme of discrimination in public debates and the very small amount of scientific research work proposing to assess the scale of the phenomenon rigorously. Merely observing that jobs are unevenly distributed between different groups of individuals can reveal inequality but does not demonstrate the presence of discrimination at job access level. Other factors can lead to uneven distribution of jobs, such as differences in productive characteristics (skill, experience, etc.) or indeed self-selection by job applicants (potential applicants can decide not to apply for a post either because their preferences lead them to make that choice, or because they anticipate the existence of discrimination in the hiring process, be they right or wrong). Heckman (1998) says that a situation of labor market discrimination appears when a firm does not reserve the same attributes (wages, access to employment, to training, to promotion, etc.) for two employees who have entirely identical productive characteristics and different non-productive characteristics. Cain (1986) distinguishes between two foundations underpinning labor market discrimination. The first, initiated by Becker (1957), is related to an aversion in certain employers to certain socio-demographic groups. Their preferences lead them to minimize all contact with those groups, even if the workers in them have productivity identical to that of the other sociodemographic groups. The second foundation, highlighted by Arrow (1972), McCall (1972), and Phelps (1972), is rooted in the observation that the employer imperfectly assesses the productivity of an applicant at the hiring stage. The recruiter then bases his or her opinion in part on a direct assessment of the applicant (academic qualifications, professional experience, success in recruitment tests) but also on beliefs about the mean and the dispersion of the productivity of the sociodemographic group to which the applicant belongs. A statistical discrimination situation arises when two applicants offering the same observable characteristics receive different treatments because the means and/or the dispersions of the productivity in their respective demographic groups are different. In addition, the existence of discrimination, be it real or assumed, can lead socio-demographic groups who are potentially discriminated against to reduce their human capital investment or to make less effort in seeking employment, so that, ex post, their performance on the labor market does indeed become lower.

Beyond these theoretical issues that emphasize the difficulty of identifying discrimination, practical implementation of measuring comes up against a problem of access to relevant data. Commonly available data do not make it possible to measure labor market discrimination satisfactorily. By definition, it relates only to the individuals who have found work, and not to the individuals who have applied for the same posts but who have not been selected. In addition, such data are subject to a problem of self-selection. Therefore, the available data are not representative of a situation in which all of the individuals apply for the vacancies that are suitable for them. Furthermore, it is not possible to base findings on direct responses from employees because they do not have access to information on the applications of their competitors, and cannot therefore know whether or not they have suffered discrimination. Neither can we base our findings on declarations made by employers because discriminatory hiring practices are illegal, and so employers tend to deny that they exist. Finally, two applications are never entirely identical and the hire decision depends on the relative importance that the employer ascribes to each productive characteristic or non-productive characteristic of the applicant.

All of these elements would argue in favor of collecting data using a controlled experiment (Petit (2003)). The right method consists in making up two totally fictitious applications that are similar except for a single characteristic that is, a priori, not productive (such as origin). The two applications are then sent in reply to the same job ads, in the same firms. This data collection technique tests access to job interviews (correspondence testing); it consists in comparing the access of the two applicants to job interviews. In a second stage, if the applications are selected by the employers, the people in charge of the study can choose to send pretend applicants to the interviews (face-to-face testing). In which case they conduct a pair audit study so as to compare the job access of the two applicants. Situation testing methods thus give a measure of labor market discrimination because they make it 
possible to compare the success rates of applicants belonging to two demographic groups, all other things remaining equal.

\section{Economic literature overview}

In the economic literature, three studies concerning discriminatory hiring practices against applicants of foreign origin are references. The first study, conducted by Riach and Rich (1991) in Australia, compared access to employment for Greek and Vietnamese minorities with access to employment for a reference group made up of Australians of Anglo-Celtic origin. Access to job interviews was tested over the period from 1983 to 1988. Three types of job were studied: white-collar employees, salespeople, and secretaries. The results showed significant discriminatory hiring practices against Greeks and Vietnamese in all three types of job. However, the Greeks suffered a lower amount of labor market discrimination than the Vietnamese.

The second study, conducted by Kenney and Wissoker (1994) in the United States, compared access to employment for young Hispanic males and for young Anglo males. The authors used the pair auditing method. They thus tested access to job interviews, and they then sent applicants to the interviews when they were invited to interviews by the employer. That study concerned itself with low-skill or "entry-level" positions. The results obtained highlighted significant discrimination against Hispanic applicants for obtaining a job interview. However, that conclusion appeared less clear cut for obtaining a job when the two applicants in the pair sat interviews. Those results would thus suggest that the discrimination was to be found above all at access-to-interview level. The simultaneous aversion of consumers and of employers to the Hispanic minority would appear to explain that community's poorer access to employment. Firstly, the discrimination was higher when the jobs involved contact with customers and when the area around the firm had a high-proportion of Anglos and of well-off residents. Secondly, discrimination was higher when the recruiter was a man and when the activity of the firm had only local scope; in which case, the hiring practices of firms are less likely to be investigated by the federal authorities. Such firms were thus less inclined to comply with the Affirmative Action directives.

The third study, conducted by Bertrand and Mullainathan (2004), compared access to job interviews for young white and young black applicants for administrative and sales jobs. The ethnic origin of the applicants was implied on the application by a forename and a surname that sound highly white American or highly Afro-American. Their results highlighted major discrimination against black applicants, of a scale that was comparable for both types of job. Furthermore, a higher-quality application benefited a white applicant to a greater extent than it did for a black applicant. However, living in a privileged neighborhood increased the probabilities of success of both black and white applicants in comparable proportions.

\section{The limits of situation testing}

The method of situation testing does however have certain limits that are important to emphasize. A first limit, highlighted by Heckman (1998), lies in the fact that the researchers who conduct the testing often claim to show aversion-based discrimination, whereas actually they are not capable of isolating it from statistical discrimination. The productivity of an employee is not fully observable at the recruitment stage: it entertains an observable component (related to the employee's academic qualifications, experience, etc.), and another component that is unobservable. In situation testing, the pairs of applicants are matched as a function of observable characteristics; the researchers conducting the situation testing implicitly consider that the effect of the unobservable characteristics is, on average, zero over all of the firms on which the experiment is done. According to Heckman (1998), that assumption can lead to erroneous assessment of discrimination in the hiring process. He shows that situation testing yields a correct measurement of aversion-based discrimination if the mean and the variance of the unobservable component of the productivity of the employees are identical in both of the demographic groups. Unfortunately, a priori, nothing indicates that that assumption is valid. If 
it is not, then situation testing yields a distorted assessment of aversion-based discrimination. Let us assume that the unobservable component of the productivity is of identical mean in both demographic groups (A and B, where group B is the group potentially discriminated against), but of different variances. Group A, in which variance is higher, is the most heterogeneous: it includes individuals having very high unobservable productivity and individuals having very low unobservable productivity. Group B, which is more homogeneous, is made up of individuals having unobservable productivity close to the mean. In which case, if applicants from groups A and B apply for low-skill jobs, employers favor those from the latter group; that is because the probability of selecting an applicant capable of occupying that type of position is higher in group B. In this case, situation testing underestimates the scale of discrimination based on aversion to group B. Conversely, if applicants from groups A and B apply for high-skill jobs, recruiters favor those from the former group because only group A includes a certain number of individuals offering very high productivity. In which case, situation testing overestimates the scale of discrimination based on aversion to group B. The validity of the conclusions of situation testing thus relies in part on the perception that the recruiters have of the compared variance of the unobserved component of productivity within the two demographic groups. Different levels of access to jobs for two demographic groups thus imply discrimination and/or different hoped-for productivity, between which the situation testing method is not capable of distinguishing.

A second limit lies in generalization of the results of situation testing. The data collected are experimental data. They give a reliable indication of the scale of discriminatory hiring practices at a given moment in time, and within the field covered by the experiment, but it can under no circumstances provide an indication of the state of discrimination throughout the labor market (De Schutter (2001)).

\section{Contribution of this study}

Prior studies on discrimination against young French people of ethnic immigrant origin are essentially concerned with wage discrimination (Bouhmadi and Giret, 2005; Aeberhart and Pouget, 2006). The authors found that almost all of the discrimination does not come from different levels of wage for identical productive characteristics but rather from problems of access to jobs, or, more generally, of access to the best paid positions. However, the data used in those studies measures access to employment only incompletely. It was therefore necessary to conduct situation testing in order to determine whether it was indeed access to jobs that was the main problem in discrimination against young French people of ethnic immigrant origin.

The object of this paper is to present the results of a test of access to job interviews for young people from the Ile-de-France Region. This correspondence testing aims to give an indication of the scale and of the determinants of discrimination in the hiring process against young people of foreign origin.

Through its construction, this situation testing seeks to take into account the above-mentioned limits. Firstly, discrimination based on origin can be triggered by various aspects, such as nationality, sound of forename and of surname, and place of residence, that should be isolated. It is possible, in particular, as suggested by Heckman (1998) that the employment access gap that works against young people of ethnic immigrant origin might result from a negative signal that they convey as regards the environment in which they live. In order take account of these aspects, four types of application were constructed: a first applicant was of Moroccan nationality and had a Moroccan-sounding forename and a Moroccan-sounding surname; a second applicant was of French nationality and had a Moroccansounding forename and a Moroccan-sounding surname; a third applicant was of French nationality and had a French-sounding forename and a Moroccan-sounding surname; and a fourth applicant was of French nationality and had a French-sounding forename and a French-sounding surname. The other characteristics of the applicants were similar. Each of the four applicants was assigned a place of residence in a "privileged" city or in an "underprivileged" city of Ile de France. In all, eight types of application were thus constructed for sending in reply to the same job ads in the same firms. 
Secondly, origin-based discrimination can vary depending on the profile of the applicant. The situation testing was thus conducted both on low-skill jobs or skilled jobs in accountancy.

Three particularities of this study can thus be highlighted. The first lies in the field that is explored: discrimination in hiring first-time employees in the Paris area. The second particularity lies in the fact that several discrimination factors are analyzed simultaneously: nationality, surname, forename, and place of residence. The methodology that we use makes it possible to assess finely to what extent these various discrimination factors actually combine and are cumulative. The third particularity lies in the facts that a rigorous protocol for collecting observations was followed, and that econometric techniques were used that enabled the reliability of our findings to be tested.

The paper is made up of two sections. The first section describes the protocol for application construction and for data collection. The presentation of the protocol followed is particularly important because it conditions the results obtained. The second section presents these results. 


\section{Data collection}

The test consisted in sending a large number of dummy resumes in reply to a sample of job vacancies available at the end of 2006 for one profession, namely accountant. The aim was to test simultaneously the effects of place of residence (privileged or underprivileged), of nationality, and of origin of surname and of forename (French or Moroccan). In this section, we describe how the data were compiled.

\section{Nature of the experiment}

\section{Eight fictitious applicants per job vacancy}

We tested three types of individual variable indicating French or foreign origin: the applicant's French or Moroccan nationality, the French-sound or Moroccan-sound of the applicant's surname, and the French-sound or Moroccan-sound of the applicant's forename (Table 1). These three characteristics were the only elements by which the applications differed, together with type of city (privileged or underprivileged). They made it possible to construct four reference profiles (Table 1) located in a suburb reputed to be underprivileged or in a suburb reputed to be privileged. In all, we thus formed 8 types of application.

The choice of Moroccan as the foreign nationality was guided by the fact that several studies show that it is the immigrants and children of immigrants of North African origin who suffer the most difficulties in accessing jobs (Richard J.-L. (2006); Silberman R. and I. Fournier (2006)).

Table 1: four types of application

\begin{tabular}{|c|c|c|c|}
\hline \hline Application & Nationality & Surname & Forename \\
\hline MMM & Moroccan & $\begin{array}{c}\text { Moroccan- } \\
\text { sounding }\end{array}$ & $\begin{array}{c}\text { Moroccan- } \\
\text { sounding }\end{array}$ \\
\hline FMM & French & $\begin{array}{c}\text { Moroccan- } \\
\text { sounding }\end{array}$ & $\begin{array}{c}\text { Moroccan- } \\
\text { sounding }\end{array}$ \\
\hline FMF & French & $\begin{array}{c}\text { Moroccan- } \\
\text { sounding }\end{array}$ & $\begin{array}{c}\text { French- } \\
\text { sounding }\end{array}$ \\
\hline FFF & French & French- & $\begin{array}{c}\text { French- } \\
\text { sounding }\end{array}$ \\
\hline \hline
\end{tabular}

These four types of application enabled us to form three pairs of applicant. Within each of the pairs, the two applicants were similar (same sex, same age, same experience, same qualifications, living in towns that were socio-economically comparable, etc.). Only one characteristic set them apart, and that characteristic had, a priori, no effect on productivity.

The first pair differed by nationality (MMM and FMM). One was Moroccan, and the other was French. Both had forenames and surnames that were Moroccan-sounding. Since otherwise the two applicants had the same characteristics, any gap in access to job interviews between them can be interpreted as being discrimination based on nationality.

A second pair differed by sound of forename (FMM and FMF). Both applicants were French and had Moroccan-sounding surnames. The only difference between the two applicants lay in one of them having a Moroccan-sounding forename while the other had a French-sounding forename. Any gap in access to job interviews between the two applicants would be indicative of the influence of a foreign forename on discrimination. 
A third pair differed by sound of surname (FMF and FFF). Both applicants were French and had French-sounding forenames. However, one had a Moroccan-sounding surname while the other had a French-sounding surname. Any gap in access to job interviews between the two applicants can be interpreted as being discrimination based on a foreign-sounding surname.

\section{The professional profiles}

We assessed discriminatory hiring practices on low-qualification positions and qualified positions in accounting trades. Employees working in accountancy have limited contact with customers, which should lessen the amount of discrimination related to real or assumed preferences of customers. This sector offered the advantage of having a large quantity of job vacancies proposed every month so as to reach a sufficient representative sample.

The low-skill jobs corresponded to accounts secretary, accountant's assistant or assistant accountant, and administrative employee positions. The level of qualification required for this type of job is an "Accounting" vocational baccalaureate. The skill jobs required a Brevet de Technicien Supérieur (BTS) in Accounting and Management for Organizations (a BTS requires two years of postbaccalaureate study). This level of qualification makes it possible to apply for sole accountant, supplier accountant, administrative manager, or management assistant jobs.

\section{Constructing the applications}

For each of the two skill levels, eight applications were constructed. They were entirely similar without being identical so as to limit the risk of detection by the recruiters. This was because all eight applications were to be sent simultaneously to the same employers in response to the same job ads.

All eight applicants were male and of the same age (20 years for the baccalaureate holders and 22 years for the BTS holders). All eight resumes were identical in terms of qualifications and experience. All eight applicants had the same diplomas obtained in June 2005. The applicants had knowledge of the same office automation and accountancy software. All of them were mobile (with vehicles) and driving license holders. Their experience was of comparable length (about one year). They did not have any periods of unemployment: they were currently in work in jobs similar to the one they were applying for. They had occupied the same types of job during internships while they were studying, and since they started working in their current jobs in the second half of 2006. The tasks they were performing in their current jobs were similar and described in detail in the resumes.

The differences appearing between the eight applications were as follows. The type font, the font size, and the layout of the resumes and of the covering letters were distinct, while remaining standard. The applicants had worked in different firms, located in different arrondissements (districts) inside Paris. They had worked in different industrial and service sectors. The leisure activities of the applicants were also different, while remaining very standard and impersonal (sport, cinema, reading, music, etc.). Mobile phone (cell phone) numbers and email addresses were also assigned to the eight applicants.

The Moroccan nationality of the MMM-type applicants appeared explicitly on their resumes. However, as is common practice, the French applicants (of the FMM, FMF, and FFF types) did not indicate any nationality; their nationality was thus suggested. It is possible that the FMM-type applicants sent the signal of having Moroccan nationality. Comparison of the results obtained by the applications of the MMM and FMM types makes it possible to examine whether the Moroccan nationality stated explicitly or merely suggested elicited different rates of access to job interviews.

All eight applicants had different forenames and surnames that were unambiguously French-sounding or Moroccan-sounding. They are given in Table 2. 
Table 2: Identity of the applicants

\begin{tabular}{|c|l|l|l|}
\hline \hline \multirow{2}{*}{ Low-skilled jobs } & \multicolumn{1}{|c|}{ MMM and FMM } & \multicolumn{1}{c|}{ FMF } & \multicolumn{1}{c|}{ FFF } \\
\hline & $\begin{array}{l}\text { DJAZOULI Medhi } \\
\text { KHALIS Ahmed } \\
\text { BENBALIT Rachid } \\
\text { ZIDAT Mourad }\end{array}$ & $\begin{array}{l}\text { LAISSAOUI Vincent } \\
\text { EL MEZOUAGHI Eric }\end{array}$ & $\begin{array}{l}\text { MEUNIER Clément } \\
\text { RIVIERE Benoît }\end{array}$ \\
\hline \multirow{2}{*}{ Skilled jobs } & $\begin{array}{l}\text { CHARBIT Selim } \\
\text { BENZAKRI Youcef } \\
\text { MOKRAOUI Yassine } \\
\text { CHAJARA Hicham }\end{array}$ & ABDALLI Stéphane & SAHRAOUI Philippe \\
\hline \hline
\end{tabular}

All eight applicants for each skill level lived in the Ile de France Region. Their place of residence appeared in their resume. Four of them, of the MMM, FMF and FFF types were located in towns reputed to be "privileged" while the other four, also of the MMM, FMF, and FFF types, were located in towns reputed to be "underprivileged". The places of residence of the applicants are given in Table 3.

Table 3: Place of residence of the applicants

\begin{tabular}{|c|c|}
\hline \hline "Underprivileged" cities & "Privileged" cities \\
\hline Epinay sur Seine (93) & Nogent sur Marne (94) \\
Bondy (93) & Le Perreux sur Marne (94) \\
Gagny (93) & Fontenay sous Bois (94) \\
Grigny (91) & Bagneux (92) \\
\hline
\end{tabular}

NB: More than one applicant can be located in the same town.

"93" is the number indicating the administrative area or "département" of Seine-Saint-Denis; "91" is the number indicating the "département" of Essonne; "94" is the number indicating the "département" of Val de Marne "92" is the number indicating the "département" of Hauts de Seine.

\section{How the experiment proceeded}

\section{Access to job interviews}

We chose not to send any applicants to the job interviews, even when the applicants were selected by the recruiters. We can thus only compare the applicants' access to the job interviews. This methodological restriction offers two advantages (Riach and Rich (1991)). Firstly, we were able to control the proceedings of the study fully. Thus, we could be sure that all of the characteristics of the applicants other their nationalities, how their forenames and surnames sounded, and the locations of their places of residence remained similar. More precisely, our results are free from distortions related to the physical appearances and personalities of the applicants since not only did the applications not contain any photographs but also the recruiters did not meet the applicants.

Secondly, the data collection procedure was simplified so that, at any given time, we were able to constitute a more substantially sized sample. In all, 1097 applications were sent over a period of two months.

Access to job interviews, in the first analysis, gives only an approximation of access to employment, but organizing interviews is costly for firms, which encourages them to interview only those applicants who actually have a real chance of obtaining the post. What is more, a decision to refuse to 
interview an applicant indicates that the potential employer is not even entertaining the possibility of recruiting that applicant.

\section{Sending the applications}

In France, the "ANPE" (Agence Nationale pour l'Emploi), which is the government-run employment agency, centralizes most of the vacancies relating to office employee positions in the service sector. We thus regularly consulted the job ads posted and updated daily by the ANPE. In order to obtain a representative sample of other sources of job vacancies, we also used databases of Internet sites specialized in job ads (monster.fr; jobtel.com, joob.fr) and the specialist press (Le Marché du Travail). No unsolicited application was sent. The applications reached the recruiters a few days after their ads appeared.

The applications were sent between the beginning of October and the end of November 2006, in response to ads corresponding to one of the four profiles. The eight applications for each job were mailed simultaneously, in order to ensure that they arrived the same day. Furthermore, they were sent from different post offices in Paris in order to limit the risk of the study being detected. For the applications that were sent by electronic mail, the emails were sent the same day with a few minutes between each transmission in order to limit the risk of detection.

We replied to all of the job ads that matched the qualifications and experience of the applications and that also satisfied the following criteria:

- Full-time job.

- $\quad$ Fixed-term or indefinite-term contract (which excluded temporary employment).

- Positions located throughout Ile de France.

In addition, in order to avoid that the style or the contents of a particular application systematically influences the firms so that they choose a particular applicant (in spite of the precautions taken when constructing the applications), we implemented a resume rotation system. The types of paper used were alternated between the applicants of each type living in privileged or underprivileged suburbs. Finally, various types of envelopes and of stamps were used in order to prevent the survey from being detected.

Processing the responses from the recruiters

A response was considered to be positive when the recruiter asked the applicant to attend an interview or when the recruiter asked for more information on the applicant's current situation or qualifications ${ }^{1}$. Conversely, a response was considered to be negative if the recruiter formally rejected the application or did not respond to it.

\footnotetext{
${ }^{1}$ When a recruiter contacted an applicant to offer an interview or to ask for more details on skills or situation, we replied that the applicant had just found a job.
} 


\section{Methodology and Results}

\section{Mean differences in the success rates over all of the vacancies: discrimination presumed}

Table 4 gives the answering rates. They are computed as the percentage of job offers that led to at least one interview proposal. We reach $12 \%$ over the total sample. It is important to notice that the success rates computed on the number of CVs are always lower than the success rates computed from the number of job offers, and clearly underestimate the true answering rates for the following reasons. First, we send a set of matched CV which include, by definition, candidates that are potentially discriminated. Therefore, we expect that only a part of the candidates will reach a positive answer for an interview. Consider the case where all the job offers get only one positive answer (a $100 \%$ answering rate) while we would send $8 \mathrm{CVs}$ on each, the CV answering rate would simply be $1 / 8=12.5 \%$ instead of $100 \%$. Second, the answering rate computed from the number of CVs tends to decrease with the number of CV send on each job offer because the more there are CVs the more there are potential cases of discrimination. This implies that the success rates computed from the number of CVs are not comparable among different studies, at least because they have different numbers of CVs sent on each job offer. The only answering rate that is comparable among studies is therefore the percentage of job offers that led to at least one interview proposal, reported in Table 4.

Table 4: Answering rates

Percentage of job offers that led to at least one interview invitation

\begin{tabular}{lc}
\hline \hline Sample & Answering rate \\
\hline Low-skilled & $6.15 \%$ \\
High-Skilled & $16.67 \%$ \\
\hline Total & $11.89 \%$ \\
\hline \hline
\end{tabular}

Table 4 gives the CV success rates of the applicants as a function of the main characteristics. Overall, only $3.1 \%$ of the applications led to being asked to attend job interviews, bearing witness to how difficult it is for unemployed jobseekers to return to work in France. Accountants and more generally administrative department technicians face a slack labor market and a higher length of time for finding a job, especially in the Paris area.

The mean success rate masks strong disparities between the applicants. The highest-qualified applicants are, on average, twice as likely to obtain a job interview. However, there is no major gap between the applicants from different cities. The widest gaps appear for origin of the applicant, expressed through nationality, sound of surname, and sound of forename.

The applicants having French surnames and forenames obtained one positive response for 14 resumes sent, on average, as against 35 resumes for an applicant having a French forename and a Moroccan surname, 54 resumes for an applicant having a Moroccan surname and a Moroccan forename, and 274 resumes for a Moroccan applicant. These first findings suggest the existence of significant discrimination on this labor market. If we assign a success index of 100 to the applicants having French surnames and forenames, an index of 40 is obtained for an applicant having a French forename and a Moroccan surname, 25 for an applicant having a Moroccan surname and a Moroccan forename, and only 5 for a Moroccan applicant. 
Table 4: Success rates of the applicants

The success rates of the table are computed overall for the survey. The responses are not matched to the same vacancies and can therefore, theoretically, differ from the success rates indicated in the other tables.

\begin{tabular}{|l|c|c|c|c|c|}
\hline \hline Field & $\begin{array}{c}\text { Number of } \\
\text { CVs }\end{array}$ & $\begin{array}{c}\text { Number of } \\
\text { Successes }\end{array}$ & $\begin{array}{c}\text { Success } \\
\text { Rate }\end{array}$ & $\begin{array}{c}90 \% \\
\text { Lower } \\
\text { Bound } 1\end{array}$ & $\begin{array}{c}90 \% \\
\text { Upper } \\
\text { Bound }^{1}\end{array}$ \\
\hline Overall & 1097 & 34 & $3.10 \%$ & $2.28 \%$ & $4.01 \%$ \\
\hline Qualification: & 491 & 9 & $1.83 \%$ & $0.81 \%$ & $2.85 \%$ \\
Baccalaureate & 606 & 25 & $4.13 \%$ & $2.81 \%$ & $5.45 \%$ \\
BTS & 549 & 16 & $2.91 \%$ & $1.82 \%$ & $4.19 \%$ \\
\hline Place of residence: & 548 & 18 & $3.28 \%$ & $2.01 \%$ & $4.56 \%$ \\
Privileged city & & & & & \\
Underprivileged suburb & 274 & 1 & $0.36 \%$ & $0.00 \%$ & $1.09 \%$ \\
\hline Seemingly origin:2 & 272 & 5 & $1.84 \%$ & $0.74 \%$ & $3.31 \%$ \\
MMM & 276 & 8 & $2.90 \%$ & $1.45 \%$ & $4.71 \%$ \\
FMM & 275 & 20 & $7.27 \%$ & $4.73 \%$ & $9.82 \%$ \\
FMF & & & & & \\
FFF & & & & & \\
\hline \hline
\end{tabular}

1. The confidence intervals have been computed by the bootstrap with 10,000 replications. They have been allowed to be asymmetric.

2. MMM: Moroccan nationality, Moroccan surname and forename; FMM: French nationality, Moroccan surname and forename; FMF: French nationality, Moroccan surname and French forename; and FFF French nationality, French surname and forename.

These initial statistics can however be criticized to some extent because they are based on an overall comparison of success rate, and not on separate comparisons for the same vacancies. Unfortunately, in order to avoid detection, we could not send all of the possible applications for the same vacancies, but rather we had to send only a portion of them, while rotating the applications over the vacancies. In order to obtain more reliable figures, it is necessary to limit the findings to the applications for the same vacancies, and then to average the resulting differences. In addition, some applications were rejected by the ANPE and, therefore, were not submitted to the employer. The results of these comparisons are given in Tables 5.

In performing these comparisons, the single effects (e.g. effect of surname) are distinguished from combined effects (e.g. effect of name and of forename). For certain vacancies, the applicants differed merely by nationality of origin of surname, and, for other vacancies, both by origin of surname and by origin of forename. The distinction is interesting because it is quite possible to find that the separate effects of surname and of forename are not significant, but the combined effect is.

\section{Measurement of the effects of nationality, surname, and forename}

The basic applications differ depending on the following three criteria:

1) Stated nationality. M: Moroccan nationality indicated on the resume. F: nationality not indicated on the resume;

2) Nationality of the surname. M: Moroccan. F: French.

3) Nationality of the forename. M: Moroccan. F: French.

On the basis of the preceding three criteria, the perceived origin of the applicant is defined: 
1) MMM: Moroccan nationality, Moroccan surname and forename;

2) FMM: French nationality, Moroccan surname and forename;

3) FMF: French nationality, Moroccan surname, and French forename; and

4) FFF: French nationality, French surname and forename.

Comparisons were then made in pairs on the same vacancies. This made it possible to isolate the effect of each of the following six characteristics on the probability of obtaining a job interview:

1) FMM - MMM: effect of nationality, for an applicant having a Moroccan surname and a Moroccan forename;

2) FMF - MMM: combined effect of nationality and forename, for an applicant having a Moroccan surname;

3) FFF - MMM: combined effect of nationality, French surname and French forename;

4) FMF - FMM: effect of forename, for an applicant having French nationality and a Moroccan surname;

5) FFF - FMM: combined effect of surname and forename, for an applicant of French nationality;

6) FMM - MMF: effect of surname, for an applicant having a French forename and French nationality.

\section{Estimation of discrimination}

In order to evaluate the significance of the success differences between the candidates, we have chosen to use the bootstrap method. We did it because we use the difference of success probabilities to test the existence of discrimination, and this statistic is asymptotically pivotal. Therefore the bootstrap approximation of its distribution is better than the corresponding asymptotic approximation (Horowitz, 2001). For the regressions that will follow, however, the bootstrap approximation is equivalent to the asymptotic approximation, so that its main interest is that is corrects for heteroskedasticity.

\section{Nationality}

The first single effect is the effect of nationality. In order to highlight it, the success rates of the applicants whose surnames and forenames were Moroccan but whose nationalities were different were compared for the same vacancies. In this way, it is possible to measure the effect that a change in the statement of nationality would apparently have for a person who retains a surname and a forename of Moroccan origin. The result is given in Table 5.

The effect given in Table 5 is a moderate one. We can observe only a slight increase in success (1.45\%), just significant at the threshold of $10 \%$. Neither is there any significant difference depending on qualification or type of city (privileged/underprivileged). This indicates that a large number of observations are necessary in order for a significant effect to appear. 
Table 5: Effects of nationality, name and forename on matched job applications

Comparisons are made on the same job offers. Several applications are sent to each job offers. The number of applications can vary from one job to another due to "pre-selection" by the ANPE. **: significant at 5\%* : significant at $10 \%$

\begin{tabular}{|c|c|c|c|c|c|c|}
\hline \multirow[t]{2}{*}{ Difference $^{1}$} & \multirow[t]{2}{*}{ Estimates $^{2}$} & \multirow[t]{2}{*}{ Total sample } & \multicolumn{2}{|c|}{ Qualification } & \multicolumn{2}{|c|}{ Type of city } \\
\hline & & & Low (Baccalauréat) & High (BTS) & Underprivileged & Privileged \\
\hline $\begin{array}{l}\text { FMM-MMM } \\
\text { Nationality }\end{array}$ & $\begin{array}{l}\text { Number of jobs offers/Number of CVs } \\
\text { Difference in success rates } \\
\text { Bootstrapped Student T } \\
\text { Number of bootstrap repetitions }\end{array}$ & $\begin{array}{c}138 / 541 \\
1.45 \% \\
1.65^{\star} \\
1006\end{array}$ & $\begin{array}{c}62 / 242 \\
0.81 \% \\
0.99 \\
1074\end{array}$ & $\begin{array}{c}76 / 299 \\
1.97 \% \\
1.40 \\
790\end{array}$ & $\begin{array}{c}135 / 270 \\
1.48 \% \\
0.97 \\
814\end{array}$ & $\begin{array}{c}133 / 266 \\
1.50 \% \\
1.48 \\
851\end{array}$ \\
\hline $\begin{array}{l}\text { FMF-MMM } \\
\text { Nationality and } \\
\text { forename }\end{array}$ & $\begin{array}{l}\text { Number of jobs offers/Number of CVs } \\
\text { Difference in success rates } \\
\text { Bootstrapped Student T } \\
\text { Number of bootstrap repetitions }\end{array}$ & $\begin{array}{c}138 / 545 \\
2.54 \% \\
2.46^{\star \star} \\
768\end{array}$ & $\begin{array}{c}62 / 245 \\
1.61 \% \\
1.49 \\
768\end{array}$ & $\begin{array}{c}76 / 300 \\
3.29 \% \\
1.95^{\star} \\
768\end{array}$ & $\begin{array}{c}136 / 272 \\
2.21 \% \\
1.33 \\
904\end{array}$ & $\begin{array}{c}134 / 268 \\
2.99 \% \\
2.02^{\star \star} \\
990\end{array}$ \\
\hline $\begin{array}{l}\text { FFF-MMM } \\
\text { Nationality, } \\
\text { name and } \\
\text { forename }\end{array}$ & $\begin{array}{l}\text { Number of jobs offers/Number of CVs } \\
\text { Difference in success rates } \\
\text { Bootstrapped Student T } \\
\text { Number of bootstrap repetitions }\end{array}$ & $\begin{array}{c}137 / 542 \\
6.93 \% \\
3.29 \star \star \\
768\end{array}$ & $\begin{array}{c}62 / 245 \\
4.84 \% \\
1.91^{\star} \\
1306\end{array}$ & $\begin{array}{l}75 / 297 \\
8.67 \% \\
2.86^{\star \star} \\
768\end{array}$ & $\begin{array}{c}134 / 268 \\
5.22 \% \\
2.26 \star \star \\
768\end{array}$ & $\begin{array}{c}134 / 268 \\
8.96 \% \\
3.55^{\star \star} \\
768\end{array}$ \\
\hline $\begin{array}{l}\text { FMF-FMM } \\
\text { Forename }\end{array}$ & $\begin{array}{l}\text { Number of jobs offers/Number of CVs } \\
\text { Difference in success rates } \\
\text { Bootstrapped Student } T \\
\text { Number of bootstrap repetitions }\end{array}$ & $\begin{array}{c}139 / 546 \\
1.08 \% \\
1.12 \\
768\end{array}$ & $\begin{array}{c}61 / 240 \\
0.82 \% \\
0.98 \\
1120\end{array}$ & $\begin{array}{c}78 / 306 \\
1.28 \% \\
0.80 \\
951\end{array}$ & $\begin{array}{c}135 / 270 \\
0.74 \% \\
0.47 \\
786\end{array}$ & $\begin{array}{c}134 / 268 \\
1.49 \% \\
0.85 \\
768\end{array}$ \\
\hline $\begin{array}{l}\text { FFF-FMM } \\
\text { Name and } \\
\text { forename }\end{array}$ & $\begin{array}{l}\text { Number of jobs offers/Number of CVs } \\
\text { Difference in success rates } \\
\text { Bootstrapped Student T } \\
\text { Number of bootstrap repetitions }\end{array}$ & $\begin{array}{c}138 / 544 \\
5.43 \% \\
2.88^{\star \star} \\
819\end{array}$ & $\begin{array}{c}62 / 243 \\
4.03 \% \\
1.71^{\star} \\
851\end{array}$ & $\begin{array}{c}76 / 301 \\
6.58 \% \\
2.56^{\star \star} \\
851\end{array}$ & $\begin{array}{c}133 / 266 \\
3.01 \% \\
1.30 \\
768\end{array}$ & $\begin{array}{c}135 / 270 \\
7.41 \% \\
2.88^{\star \star} \\
834\end{array}$ \\
\hline $\begin{array}{l}\text { FFF-FMF } \\
\text { Name }\end{array}$ & $\begin{array}{l}\text { Number of jobs offers/Number of CVs } \\
\text { Difference in success rates } \\
\text { Bootstrapped Student T } \\
\text { Number of bootstrap repetitions }\end{array}$ & $\begin{array}{c}137 / 546 \\
4.38 \% \\
2.52^{\star \star} \\
768\end{array}$ & $\begin{array}{c}61 / 243 \\
3.28 \% \\
1.61 \\
864\end{array}$ & $\begin{array}{c}76 / 303 \\
5.26 \% \\
1.93^{\star} \\
770\end{array}$ & $\begin{array}{c}136 / 272 \\
2.94 \% \\
1.14 \\
768\end{array}$ & $\begin{array}{c}136 / 272 \\
5.88 \% \\
2.58^{\star \star} \\
773\end{array}$ \\
\hline
\end{tabular}

1. MMM: Moroccan nationality, name and forename. FMM: French nationality, Moroccan name and forename. FMF: French nationality, Moroccan name and French forename. FFF: French nationality, name and forename.

2. The number of bootstrap repetitions is determined according to Andrews and Buchinsky (2000, 2001). We set that our bootstrapped estimates should not depart from more than $5 \%$ to the ideal bootstrap estimate with a probability equal to $95 \%$ (i.e., pdb=5 and $\tau=0.05$ ). 
Let us now assume that the application changes not only nationality but also forename, by adopting a French forename. The success rate increases by $2.54 \%$ and the effect is significant at $5 \%$. If we look in more detail, we note, however, that only certain applicants significantly improve their chances of obtaining a job interview: the highest-qualified ones who have a BTS rather than a baccalaureate $(+3.29 \%)$, and those who live in a privileged city rather than an underprivileged one $(+2.99 \%)$.

And if the applicant changes nationality, surname, and forename, do we find a stronger effect? Indisputably we do. The increase is by $6.93 \%$ and, this time, it concerns all applicants, from the highest-qualified $(+8.67 \%)$ to the lowest-qualified $(+4.84 \%)$, and both those living in underprivileged cities (5.22\%) and those living in privileged cities $(+8.96 \%)$. The strongest gain is made by the highest-qualified candidates living in the privileged cities.

\section{Forename}

The second single effect is the effect of forename. Two applicants of French nationality and of Moroccan surname were compared. Only the forename changed. Having a French forename does not significantly change the success rate.

Let us now assume that the applicant of Moroccan surname and forename, assumes a French surname and a French forename. The combined effect of surname and forename is significant for all the candidates but the ones living in underprivileged cities. The global increase in the success rate increases is $+5.43 \%$, while it is $+6.58 \%$ for the highest-qualified, $+4.03 \%$ for the lowest-qualified and $+7.41 \%$ for those living in privileged cities.

\section{Surname}

The last single effect is that of surname. The applicants having French nationality and a French forename were compared while changing merely the nationality of the surname. The difference is significant (4.38\%) and mainly concerns the applicants who are the highest-qualified $(+5.26 \%)$ and the ones who live in privileged cities $(+5.88 \%)$.

\section{Place of residence}

The previous results show that there are success rate differences depending on the city of residence. But the latter variable is merely a control, so that an additional analysis, on matched job offers must be performed in order to reach a robust conclusion. This is obtained by comparing the success rates, for the same vacancies, of the applicants residing in underprivileged cities with the success rates of the other applicants. The single effect is distinguished from the crossed effects, i.e. from the effects limited to sub-populations (qualified/non-qualified, etc.). We find no significant effect of the place of residence (Table 6), even when a comparison is conducted by qualification (BTS/Baccalaureate) or by profile (MMM, FMM, FMF, FFF). 
Table 6: Effects of the city of residence on matched job applications

Comparisons are made on the same job offers. Several applications are sent to each job offer. The number of applications can vary from one job to another due to "pre-selection" by the ANPE. No difference is significant at the $10 \%$ level.

\begin{tabular}{|l|c|c|c|c|}
\hline \hline & $\begin{array}{c}\text { Number of job } \\
\text { offers/Number } \\
\text { of CVs }\end{array}$ & $\begin{array}{c}\text { Difference in } \\
\text { success rates }\end{array}$ & $\begin{array}{c}\text { Bootstrapped Student } \\
\text { T }\end{array}$ & $\begin{array}{c}\text { Number of bootstrap } \\
\text { repetitions }^{1}\end{array}$ \\
\hline Sample: & $140 / 1092$ & $0.30 \%$ & 0.49 & 768 \\
All observations & $63 / 489$ & $0.26 \%$ & 0.35 & 798 \\
Low qualification (Baccalauréat) & $77 / 603$ & $0.32 \%$ & 0.38 & 768 \\
High qualification (BTS) & & & & 8057 \\
Seemingly origin:2 & $134 / 268$ & $-0.75 \%$ & 0.99 & 824 \\
MMM & $132 / 264$ & $-0.76 \%$ & 0.45 & 768 \\
FMM & $136 / 272$ & $0.00 \%$ & 0.00 & 1.45 \\
FMF & $136 / 272$ & $2.94 \%$ & & 806 \\
FFF & & & & \\
\hline \hline
\end{tabular}

1. The number of bootstrap repetitions is determined according to Andrews and Buchinsky $(2000,2001)$. We set that our bootstrapped estimate should not depart from more than $5 \%$ to the ideal bootstrap estimate with a probability equal to $95 \%$ (i.e., $p d b=5$ and $\tau=0.05$ ).

2. MMM: Moroccan nationality, name and forename. FMM: French nationality, Moroccan name and forename. FMF: French nationality, Moroccan name and French forename. FFF: French nationality, name and forename.

\section{Regression analysis : discrimination confirmed}

In order to perform a regression analysis, we will consider an overall discrimination measurement on all the answers to each of the job vacancies. The reference group will be the FFF, compared with the average of the other groups.

Analysis at the vacancy level

For each vacancy, we have a certain number of responses for both of the study groups (FFF and the others). It is thus possible to compute, within each vacancy, success rates for both groups. For each comparison, we have $\mathrm{N}$ vacancies and, for each vacancy, there are $\mathrm{C}$ applicants belonging to two different groups. In practice, following rejection of certain applications by the ANPE, the number of applicants can vary for each vacancy. For vacancy number $i$, we have $C_{i}$ applicants $(i=1, \ldots, N)$ whose index $\mathrm{j}$ varies from 1 to $\mathrm{C}_{\mathrm{i}}$. By convention, the reference group is identified with an index $\mathrm{k}=0$, and the comparison group is identified by an index $\mathrm{k}=1$. For each vacancy, we have two success rates:

$$
\bar{y}_{k, i}=\frac{1}{C_{i}} \sum_{j=1}^{C_{i}} y_{k, j, i}, \quad k \in\{0,1\}, i=1, \ldots, N
$$

The measurement of net discrimination is thus equal to:

$$
\Delta=\frac{1}{\mathrm{~N}} \sum_{\mathrm{i}=1}^{\mathrm{N}}\left(\overline{\mathrm{y}}_{1, \mathrm{i}}-\overline{\mathrm{y}}_{0, \mathrm{i}}\right)
$$

In the case of regressions, this measurement is explained by a set of explanatory variables. Here, two cases can arise: either the characteristic whose effect is being studied is exactly the same for both of the individuals, and it must be put in level in the model, or else it is different and it must be put both in level and in difference in the model. For both types of variable, only the variables in levels indicate conditional discrimination. 


\section{Linear regression and decomposition}

With experimental data it is possible to define a variant of the Blinder-Oaxaca decomposition (1973) that makes it possible to improve the estimation of discrimination compared with mere comparison of means. The main difference with the Blinder-Oaxaca method lies in the fact that two separate regressions (depending on group) are not necessary because we do observe the two potential results of the recruitment process. On the experimental data, we observe both the response from the employer when the person belongs to the potentially privileged group and what the employer would have responded if the person had belonged to another group. We thus do not need to make any prediction in the latter case. This implies that a single, overall regression is necessary instead of two with the Blinder-Oaxaca method.

The set of explanatory variables of the model can be decomposed into two parts: the variables referenced $\mathrm{z}$ which take different values for the FFF applicants and for the others, and the variables referenced $\mathrm{x}$ which always take the same value in both of the groups. For the $\mathrm{x}$ variables, the difference in the mean values of the two groups is always zero.

We assume that the probability of obtaining a job interview is of the following form: ${ }^{1}$

$$
\mathrm{E}\left(\mathrm{p}_{\mathrm{k}}\right)=\mathrm{zb}_{\mathrm{k}}+\mathrm{xc}_{\mathrm{k}}, \mathrm{k} \in\{0,1\},
$$

This implies that the difference in the success rates between the group of FFF applicants (referenced 1) and the group of other applicants (referenced 0 ) can be written, using $\mathrm{x}_{1}=\mathrm{x}_{0}$ :

$$
\begin{aligned}
\mathrm{E}\left(\mathrm{p}_{1}-\mathrm{p}_{0}\right) & =\mathrm{z}_{1} \mathrm{~b}_{1}+\mathrm{x}_{0} \mathrm{c}_{1}-\left(\mathrm{z}_{0} \mathrm{~b}_{0}+\mathrm{x}_{0} \mathrm{c}_{0}\right) \\
& =\mathrm{z}_{1} \mathrm{~b}_{1}-\mathrm{z}_{0} \mathrm{~b}_{0}+\mathrm{x}_{0}\left(\mathrm{c}_{1}-\mathrm{c}_{0}\right) \\
& =\left(\mathrm{z}_{1}-\mathrm{z}_{0}\right) \mathrm{b}_{1}+\mathrm{z}_{0} \mathrm{~b}_{1}+\mathrm{x}_{0}\left(\mathrm{c}_{1}-\mathrm{c}_{0}\right) \\
& =\left(\mathrm{z}_{1}-\mathrm{z}_{0}\right) \mathrm{b}_{1}+\left(\mathrm{z}_{0}, \mathrm{x}_{0}\right)\left(\begin{array}{c}
\mathrm{b}_{1}-\mathrm{b}_{0} \\
\mathrm{c}_{1}-\mathrm{c}_{0}
\end{array}\right)
\end{aligned}
$$

Thus we need to regress the difference in the proportions of success of the two groups on the difference in the mean characteristics of the variables $\mathrm{z}$ and on the levels of all of the variables $\mathrm{z}$ and $\mathrm{x}$. This explains the shape of the model presented in Table 12. The coefficients of the differences do not, by definition, represent a measurement of discrimination; however, the coefficients of the variables in levels measure conditional discrimination.

\section{Estimation of the standard errors}

Since we have 140 job vacancies, our regressions are conducted on a small number of observations. Therefore we take some care in computing the standard errors. We have computed the three following standard errors :

- the OLS standard errors ;

- the White heteroskedasticity-robust standard errors;

- $\quad$ the bootstrapped standard errors ${ }^{2}$;

\footnotetext{
${ }^{1}$ We have checked that this linear form gives admissible predictions. See Appendix A.

${ }^{2}$ All the computations have been performed under SAS-IML.
} 
It is shown in appendix that OLS standard errors (Table D.1) give misleading significance results : a type of stamp ("Cubitus") used in sending the applications would be significant according to the OLS standard errors, while the other methods both conclude it does not. The White's standard errors perform better (Table D.2), in the sense that the full application of the backward elimination procedures gives the same result as the bootstrap. However, the Cubitus stamp dummy is always significant at the beginning of the backward elimination procedure with the White's standard errors. The bootstrap gives a different result : the Cubitus stamp dummy is significant only once at $10 \%$ over all the backward procedure (Table 12). Since this stamp was used for only $4 \%$ of the applications, we conclude that the OLS standard errors, and possibly White's standard errors, could be more sensitive to outliers in our application.

Conditional discriminations: impacts of distance between home and work, of status of the job sought, and of intermediation by the ANPE

In order to prevent an experiment being detected by the employer, it is necessary to make the applications differ by modifying certain characteristics at the margin. It is thus possible to study the effects of such changes in characteristics on the probability of obtaining a job interview, in particular since certain forms of discrimination can be conditional, i.e. can appear for only certain characteristics of the applicant. The only way of correcting such differences is to perform a regression in order to remove the differences between the applicants and in order to measure a net discrimination coefficient, once all of the differences between them have been removed, and not only the main differences. In order to have a sufficient number of observations, the differences between only two groups of applicants are studied, namely the FFF applicants and all of the other applicants. Compared with the usual econometric methods, our data present a particularity: they are matched on the same vacancies. The explained variable is the difference between the success rate obtained, for each vacancy, by the FFF applicants and the success rate obtained by the other applicants. The precise method is explained in the appendix, which also gives the empirical verification that the linear model is properly suited to the data.

The results are presented in Table 7. The first column ("mean discrimination coefficient") represents the overall discrimination measurement of the study, once all of the effects related to the differences in the applications have been removed. For technical reasons, we comment on the results of the estimation by progressive elimination of the non-significant variables at the threshold of $10 \%$ (last row of the table). The mean discrimination over the study is 5.5\% in the accounting sector. That figure represents the gain of an FFF applicant over another applicant (FMF, FMM, MMM), all other things remaining equal.

The "variables in differences" part presents the differences in success rate that result from the differences in the applications. They cannot be attributed to discrimination. The "variables in levels" part of Table 7 presents the influence of the variables that are identical for each vacancy for all of the applicants. It represents the increase or the decrease in discrimination as a function of the type of vacancy that is applied for. It is a conditional discrimination in the sense that it occurs only if a condition is satisfied. 


\section{Table 7 : Conditional discrimination (Backward elimination procedure based on the bootstrapped standard errors)}

Explained variable: difference in success rates for the same vacancy between the FFF applicants and the other applicants.

Bootstrapped Student $t$ between parentheses. For each regression, the number of drawings is determined by the Andrews and Buchinsky method (1998). Each regression is checked for near multicolinearity by imposing a minimum eigenvalue on the cross product of the explanative variables (as indicated in the text). The right-hand variables are centered before to run each regression, so that the intercept of the model gives the discrimination coefficient at the mean point of the sample. ** : significant at 5\% * : significant at $10 \%$

\begin{tabular}{|c|c|c|c|c|c|c|c|c|c|c|c|c|c|c|c|c|}
\hline $\begin{array}{l}\text { Regression } \\
\text { (B=number } \\
\text { of samples) }\end{array}$ & Statistic & $\begin{array}{c}\text { Mean } \\
\text { discrimination } \\
\text { coefficient }\end{array}$ & $\begin{array}{l}\text { Residence } \\
\text { in an } \\
\text { under- } \\
\text { privileged } \\
\text { city/FFF }\end{array}$ & $\begin{array}{l}\text { Cubitus } \\
\text { Stamp } \\
\text { /FFF }\end{array}$ & $\begin{array}{c}\text { Pre- } \\
\text { stamped } \\
\text { letter / } \\
\text { FFF }\end{array}$ & $\begin{array}{c}\text { Commur } \\
\text { ting time } \\
\text { /FFF }\end{array}$ & $\begin{array}{l}\text { Residence } \\
\text { in an } \\
\text { under- } \\
\text { privileged } \\
\text { city }\end{array}$ & $\begin{array}{l}\text { Cubitus } \\
\text { Stamp }\end{array}$ & $\begin{array}{c}\text { Pre- } \\
\text { stamped } \\
\text { letter }\end{array}$ & $\begin{array}{l}\text { Commu- } \\
\text { ting time }\end{array}$ & $\begin{array}{l}\text { Use of } \\
\text { Email }\end{array}$ & $\begin{array}{l}\text { Indefinite } \\
\text { term } \\
\text { contract }\end{array}$ & $\begin{array}{l}\text { Subsidiary } \\
\text { of a large } \\
\text { corporation }\end{array}$ & $\begin{array}{l}\text { Through } \\
\text { the } \\
\text { ANPE }\end{array}$ & $\begin{array}{c}\text { Resume } \\
\text { template } \\
\text { No. } 2\end{array}$ & $\begin{array}{c}\text { Job located } \\
\text { in Paris } \\
\text { itself }\end{array}$ \\
\hline & & Intercept & \multicolumn{4}{|c|}{ Variables in differences } & \multicolumn{10}{|c|}{ Variables in levels } \\
\hline \multirow{2}{*}{$\begin{array}{c}1 \\
(B=835)\end{array}$} & Coeff & 0.056 & -0.260 & -0.343 & 0.793 & -0.004 & 0.482 & 0.750 & -1.073 & 0.002 & -0.211 & -0.059 & -0.081 & -0.109 & -0.049 & 0.054 \\
\hline & Student & $3.228^{\star \star}$ & 0.276 & 0.514 & 0.742 & $1.748^{\star}$ & 0.311 & 0.829 & 0.748 & 0.732 & 0.566 & $1.667^{*}$ & $2.226^{\star \star}$ & $1.866^{\star}$ & 0.658 & 1.250 \\
\hline \multirow{2}{*}{$\begin{array}{c}2 \\
(B=1195)\end{array}$} & Coeff & 0.056 & & -0.372 & 0.658 & -0.004 & 0.049 & 0.794 & -0.888 & 0.002 & -0.163 & -0.060 & -0.079 & -0.107 & -0.053 & 0.055 \\
\hline & Student & $3.084^{\star \star}$ & & 0.474 & 0.719 & $1.685^{\star}$ & 0.092 & 0.740 & 0.715 & 0.720 & 0.440 & 1.565 & $2.226^{\star \star}$ & $1.926^{\star}$ & 0.741 & 1.297 \\
\hline \multirow{2}{*}{$\begin{array}{c}3 \\
(B=1685)\end{array}$} & Coeff & 0.056 & & -0.351 & 0.662 & -0.004 & & 0.768 & -0.890 & 0.002 & -0.165 & -0.060 & -0.080 & -0.107 & -0.051 & 0.055 \\
\hline & Student & $3.314^{\star \star}$ & & 0.574 & 0.776 & $1.728^{\star}$ & & 0.912 & 0.781 & 0.729 & 0.564 & 1.608 & $2.302^{\star \star}$ & $1.969^{\star \star}$ & 0.769 & 1.360 \\
\hline \multirow{2}{*}{$\begin{array}{c}4 \\
(B=768)\end{array}$} & Coeff & 0.056 & & -0.423 & 0.259 & -0.004 & & 0.904 & -0.310 & 0.002 & & -0.057 & -0.088 & -0.102 & -0.044 & 0.058 \\
\hline & Student & $3.158^{\star \star}$ & & 0.797 & 0.775 & $1.678^{\star}$ & & 1.176 & 0.772 & 0.725 & & 1.569 & $2.504^{\star \star}$ & $1.789^{\star}$ & 0.732 & 1.398 \\
\hline \multirow{2}{*}{$\begin{array}{c}5 \\
(B=768)\end{array}$} & Coeff & 0.056 & & -0.419 & 0.263 & -0.003 & & 0.890 & -0.321 & & & -0.058 & -0.087 & -0.102 & -0.044 & 0.045 \\
\hline & Student & $3.216^{\star \star}$ & & 0.930 & 0.856 & $2.017^{\star \star}$ & & 1.330 & 0.890 & & & $1.713^{\star}$ & $2.480^{\star \star}$ & $1.826^{\star}$ & 0.719 & 1.088 \\
\hline \multirow{2}{*}{$\begin{array}{c}6 \\
(B=768)\end{array}$} & Coeff & 0.056 & & -0.426 & 0.341 & -0.003 & & 0.880 & -0.429 & & & -0.061 & -0.089 & -0.103 & & 0.048 \\
\hline & Student & $3.216^{\star \star}$ & & 1.033 & 1.197 & $1.995^{* *}$ & & 1.396 & 1.327 & & & $1.752^{\star}$ & $2.586^{\star *}$ & $1.884^{\star}$ & & 1.194 \\
\hline \multirow{2}{*}{$\begin{array}{c}7 \\
(\mathrm{~B}=768) \\
\end{array}$} & Coeff & 0.056 & & & 0.130 & -0.003 & & 0.319 & -0.128 & & & -0.063 & -0.087 & -0.100 & & 0.046 \\
\hline & Student & $3.092^{\star \star}$ & & & 0.874 & $1.900^{*}$ & & 1.526 & 1.004 & & & $1.716^{\star}$ & $2.476^{\star \star}$ & $1.893^{\star}$ & & 1.172 \\
\hline \multirow{2}{*}{$\begin{array}{c}8 \\
(B=768) \\
\end{array}$} & Coeff & 0.056 & & & & -0.003 & & 0.267 & -0.007 & & & -0.066 & -0.087 & -0.102 & & 0.045 \\
\hline & Student & $3.092^{\star \star}$ & & & & $1.850^{\star}$ & & 1.365 & 0.091 & & & $1.875^{\star}$ & $2.494^{\star \star}$ & $1.918^{\star}$ & & 1.165 \\
\hline \multirow{2}{*}{$\begin{array}{c}9 \\
(\mathrm{~B}=768)\end{array}$} & Coeff & 0.056 & & & & -0.003 & & 0.266 & & & & -0.066 & -0.087 & -0.102 & & 0.045 \\
\hline & Student & $3.092^{\star \star}$ & & & & $1.858^{\star}$ & & 1.358 & & & & $1.889^{\star}$ & $2.517^{\star \star}$ & $1.914^{\star}$ & & 1.188 \\
\hline \multirow{2}{*}{$\begin{array}{c}10 \\
(B=768)\end{array}$} & Coeff & 0.056 & & & & -0.003 & & 0.252 & & & & -0.064 & -0.090 & -0.106 & & \\
\hline & Student & $3.117^{\star \star}$ & & & & $2.092^{\star \star}$ & & 1.257 & & & & $1.824^{\star}$ & $2.562^{\star \star}$ & $1.855^{\star}$ & & \\
\hline \multirow{2}{*}{$\begin{array}{c}11 \\
(B=768)\end{array}$} & Coeff & 0.056 & & & & -0.002 & & & & & & -0.070 & -0.089 & -0.138 & & \\
\hline & Student & $3.117^{\star \star}$ & & & & $1.799^{\star}$ & & & & & & $1.853^{\star}$ & $2.606^{\star \star}$ & $2.607^{\star \star}$ & & \\
\hline
\end{tabular}


Three characteristics reduce discrimination: firstly going through the ANPE rather than other intermediaries (-13.7\%), secondly applying for a vacancy proposed by a firm that is a subsidiary of a large corporation (-8.9\%), and thirdly applying for an indefinite-term contract (-6.9\%). We should note here that, since our reasoning is on the difference between the success rates of the FFF applicants and of the other applicants, a negative coefficient indicates relative discrimination against the FFF applicants. They have less change of success through the ANPE, for firms who are subsidiaries of large corporations, and for indefinite-term contracts.

These results can be explained as follows. For the ANPE, the result can be explained by the following two arguments. Firstly, the effects of the actions for heightening awareness of discrimination that are conducted by the ANPE with its employees, and, through its employees, with the employers who use the ANPE. Secondly, for this reason, it might be thought that employers who wish to discriminate would use the ANPE less often than other employers would. As regards the subsidiary effect, it might be a consequence of the various "diversity charters" that have developed in recent years in large corporations. Small businesses who are not subsidiaries are doubtless less aware of the theme of discrimination.

The effect of indefinite-term employment contracts can be explained by different beliefs about the candidates. Indeed, short-term contracts are used mainly for two purposes : first, replacing quickly a worker over a precisely defined period; second, imposing a trial period before a long-term contract. If the employer believes that the average productivity of the FFF is higher, it will take less (believed) risk by recruiting a FFF candidate for a replacement; moreover, it can transform the short-term contract into a long-term contract after one year. For the foreign origin candidates, the long-term contracts involve a more careful check of the candidate and additional examinations that we were not able to follow in this study. It is likely that the probability of success is lower for a long-term contract than for a short-term contract. Far from being an advantage, being invited to an interview for a longterm contract may reflect the will of the employer to test the candidate more deeply on his accounting skills. Therefore, our results suggest than the FFF would be selected by an "on-the-job" process, while the other candidates would be subject to more prior testing than the FFF candidates (a "before-the-job" process). Therefore, we should remain cautious about our result on the long-term contract, since it could reflect a harder test at the hiring stage for the foreign origin candidates.

\section{Additional estimates}

The previous estimates are performed at the job offer level, but we can also go in more details and perform an similar regression at the CV level. More precisely, for each offer we match the candidates with a foreign origin to their FFF counterpart. This way, we get three possible difference :

$$
y_{i}=\left\{\begin{array}{ccc}
-1 & \text { if } & \text { minority prefered } \\
0 & \text { if } & \text { equal treatment } \\
1 & \text { if } & \text { FFF prefered }
\end{array}\right.
$$

notice that there are three times more observations with this convention that with the previous regressions on the proportions. This left-hand variable must be estimated with an 3-level ordered model. We have compared the ordered Logit model with the ordered Probit model. The Vuong test concludes that they are equivalent. We comment on the ordered Logit, which results are reported in Table 8. 
Table 8: Ordered Logit estimates

Maximum likelihood estimates of the ordered Logit model. Left-hand variable: difference of treatment between the FFF candidate and the current candidate ( $-1=$ minority preferred, $0=$ equal treatment, $1=$ FFF preferred).

*: significant at the $5 \%$ level; **: significant at the $10 \%$ level.

\begin{tabular}{|c|c|c|c|c|c|}
\hline & & \multicolumn{2}{|c|}{ With all variables } & \multicolumn{2}{|c|}{$\begin{array}{l}\text { After backward } \\
\text { elimination }\end{array}$} \\
\hline & & Coefficient & $\begin{array}{l}\text { Student } \\
\text { statistic }\end{array}$ & Coefficient & $\begin{array}{l}\text { Student } \\
\text { statistic }\end{array}$ \\
\hline & $\begin{array}{l}\text { 1st intercept } \\
\text { 2nd intercept }\end{array}$ & $\begin{array}{l}-3.207 \\
5.923\end{array}$ & $\begin{array}{l}15.36^{\star *} \\
11.71^{\star *}\end{array}$ & $\begin{array}{l}-3.121 \\
5.810\end{array}$ & $\begin{array}{l}15.99^{\star *} \\
11.77^{* *}\end{array}$ \\
\hline $\begin{array}{l}\text { Variables } \\
\text { in } \\
\text { differences }\end{array}$ & $\begin{array}{l}\text { Residence in an under-privileged city/FFF } \\
\text { Cubitus Stamp /FFF } \\
\text { Pre-stamped letter / FFF } \\
\text { Commuting time /FFF }\end{array}$ & $\begin{array}{r}0.034 \\
0.414 \\
-0.156 \\
-0.021\end{array}$ & $\begin{array}{l}0.07 \\
0.62 \\
0.22 \\
1.16\end{array}$ & -0.036 & $3.20^{\star \star}$ \\
\hline \multirow[t]{2}{*}{$\begin{array}{c}\text { Variables } \\
\text { in } \\
\text { levels }\end{array}$} & $\begin{array}{l}\text { Residence in an under-privileged city } \\
\text { Cubitus Stamp } \\
\text { Pre-stamped letter } \\
\text { Commuting time } \\
\text { Use of Email } \\
\text { Indefinite term contract } \\
\text { Subsidiary of a large corporation } \\
\text { Through the ANPE } \\
\text { Resume template No. } 2 \\
\text { Job located in Paris itself }\end{array}$ & $\begin{array}{l}-0.177 \\
-0.232 \\
-0.480 \\
0.031 \\
-0.032 \\
-1.142 \\
-1.719 \\
-2.003 \\
-0.469 \\
0.907\end{array}$ & $\begin{array}{l}0.38 \\
0.21 \\
0.55 \\
1.25 \\
0.07 \\
3.44^{\star \star} \\
3.86^{\star \star} \\
5.85^{\star \star} \\
0.96 \\
2.45^{\star \star}\end{array}$ & $\begin{array}{r}-1.121 \\
-1.689 \\
-1.944 \\
0.686\end{array}$ & $\begin{array}{l}3.60^{\star *} \\
3.87^{\star \star} \\
6.12^{\star *} \\
2.42^{\star *}\end{array}$ \\
\hline & $\begin{array}{l}\text { Mc Fadden } \mathrm{R}^{2} \\
\text { Adjusted Mc Fadden } \mathrm{R}^{2} \\
\% \text { concordant predictions } \\
\text { Vuong statistic: Ordered Logit versus Ordered Probit } \\
\text { Vuong statistic : p-value (unilateral test) }\end{array}$ & $\begin{array}{l}0.1 \\
0.1 \\
80 \\
0.1 \\
0.4\end{array}$ & & $\begin{array}{r}0.1 \\
0.1 \\
79 \\
-0.0 \\
0.4\end{array}$ & \\
\hline
\end{tabular}

We reach the same conclusion that with the OLS on the proportion, except for one variable. The jobs located in Paris intra muros would increase discrimination against the foreign origin candidates, compared to the jobs in the Paris suburbs. In order to check this on raw data, we have performed a difference-in-differences analysis reported in Table 9. We find that the Paris effect is significant for the FMM candidates only, who suffer additional discrimination when the job is located inside Paris. The reason why the OLS fail to detect the Paris effect could come from the aggregation of the success rate of all non FFF candidates in a linear manner. Out of the three possible effects, only one is significant for the FMM applicants, and it is mixed with two effects that are not significant. 
Table 9: Difference-in-differences (Paris effect)

** : significant at 5\%; * : significant at $10 \%$

\begin{tabular}{|l|c|c|c|}
\hline \hline $\begin{array}{l}\text { Difference of success rate } \\
\text { between the FFF candidate and } \\
\text { the indicated candidate }\end{array}$ & $\begin{array}{c}\text { Paris intra } \\
\text { muros } \\
(1)\end{array}$ & $\begin{array}{c}\text { Paris suburbs } \\
(2)\end{array}$ & $\begin{array}{c}\text { Difference in } \\
\text { differences } \\
(1)-(2)\end{array}$ \\
\hline FMM candidate & $12.1 \%$ & $3.7 \%$ & $8.5 \%$ \\
Bootstrapped Student & $3.59^{\star *}$ & $2.52^{\star *}$ & $2.30^{\star *}$ \\
FMF candidate & $9.3 \%$ & $3.6 \%$ & $5.7 \%$ \\
Bootstrapped Student & $2.99^{\star *}$ & $1.91^{*}$ & 1.57 \\
MMM candidate & $10.3 \%$ & $4.9 \%$ & $5.4 \%$ \\
Bootstrapped Student & $3.52^{\star *}$ & $2.62^{\star *}$ & 1.55 \\
\hline \hline
\end{tabular}

The Student statistics have been computed by the bootstrap with 10,000 replications. 


\section{Conclusion}

In order to measure the scale of discriminatory hiring practices suffered by young people of foreign origin in the suburbs of Ile-de-France, we have, in this paper, presented the results of a controlled experiment conducted on accountants. For the purposes of conducting this experiment we constructed 16 jobseeker profiles and sent 1097 replies to 140 job vacancies advertised from October to November 2006. The aim of the experiment was to test simultaneously the effects of place of residence (privileged or underprivileged), of nationality, and of origin of surname and forename (French or Moroccan) on the chances of being asked to a job interview. The idea was to analyze the joint effects of various discrimination factors, such as place of residence and the elements indicating nationality of origin by using reliable measurement that is based on a rigorous protocol for collecting observations and that uses statistical and econometric techniques making it possible to verify the significance of the results.

A first conclusion emerges from this study. It concerns the scale of the discrimination against young people of ethnic origin from the suburbs of Ile-de-France. When seeking a job as an accountant, the chances of obtaining a job interview are much higher for applicants who signal that they are of French origin by the sounds of their surnames or of their forenames than for applicants who signal that they are of Moroccan nationality or of Moroccan origin. Applicants of Moroccan nationality and origin must, on average, send over ten times as many resumes in order to obtain the same number of invitations to job interviews as applicants whose surnames and forenames are of French origin. These considerable differences, present in the raw data, were generally confirmed by the statistical tests leading to a robust conclusion of a diagnostic of major discriminatory hiring practices against young people of foreign origin. Overall, this conclusion goes in the same direction as the ILO related works on European countries (Taran, 2005; Attström, 2007, Cediey and Foroni, 2007), even though they use a different methodology and job coverage.

With that first conclusion established, it can also be observed that indicating Moroccan nationality on a resume or having a Moroccan forename is less of a handicap than having a Moroccan-sounding surname. It can also be noted that going through the ANPE can reduce the risk of being a victim of discriminatory hiring practices. 


\section{References}

Aeberhart R and J. Pouget, (2006). "National origin wage differentials in France: evidence from matched employer-employee data”. Mimeo CREST-INSEE.

Andrews D. and M. Buchinsky (2000). "A Three-Step Method for Choosing the Number of Bootstrap Repetitions”. Econometrica, vol. 68(1), 23-51.

Arrow K.J. (1972), “The theory of job discrimination”, In Ashenfelter O.A. \& Reeds A. eds, Discrimination in Labor Markets, Princeton University Press, 3-33.

Attström L. (2007). "Discrimination against native Swedes of immigrant origin in access to employment”. International Labor Organization, International Migration Papers 86E.

Becker G. (1957), The Economics of Discrimination, University of Chicago Press.

Bertrand M. and Mullainathan S. (2004). "Are Emily and Greg More Employable than Lakisha and Jamal? A Field Experiment on Labor Market Discrimination” American Economic Review, vol. 94(4), pages 991-1013.

Boumahdi R. et J.-F. Giret, (2005). "Une analyse économétrique des disparités d'accès à l'emploi et de rémunérations entre jeunes d'origine française et jeunes issus de l'immigration”. Revue Economique, 56(3), 625-636.

Cain G. (1986), “The economic analysis of labor market discrimination: a survey”, Handbook of Labor Economics, vol 1, p 694-785.

Cediey E. et F. Foroni (2007). «La discrimination à raison de l'origine dans les embauches en France ». Mimeo, Bureau International du Travail.

Dayan J.L., Echardour A., Glaude M. (1996), "Le parcours professionnel des immigrés en France: une analyse longitudinale”, Économie et statistique, No. 299.

De Schutter O. (2001) Discriminations sur le marché du travail, Liberté et égalité dans les rapports à l'emploi, collection Travail et société, No. 28, Brussels, P.I.E. - Peter Lang.

Duguet E. and P. Petit (2005), "Hiring discrimination in the French financial sector: an econometric analysis on field experiment data”, Annales d'Economie et de Statistiques, No. 78, pp 79-102.

Garner-Moyer H. (2003), “Discrimination et emploi : revue de la littérature”. Working paper, DARES, No. 69, May.

Heckman J.J. (1998), “Detecting Discrimination”, Journal of Economic Perspectives, Spring, Vol. 12, No. 2, pp 101-116.

Horowitz (2002) "The bootstrap". Handbook of Econometrics, vol 5., chp. 52, pp. 3159-3228.

Kenney G.M., Wissoker D.A. (1994), “An Analysis of the Correlates of Discrimination Facing Young Hispanic Job Seekers”, American Economic Review, vol 84, No. 3, p674-683.

McCall J.J. (1972), “The simple mathematics of information, job search and prejudice”, In Pascal A.H. ed, Racial discrimination in Economic Life, Lexington Books, p205-224.

Magain D. (2006), "Discrimination positive : un bilan des experiences américaines et européennes”, Revue Française d'Economie, No. 2/vol XXI.

Petit P. (2003), “Comment évaluer la discrimination à l'embauche ?” Revue Française d'Économie, 17 (3), pp. 55-87.

Phelps E.S. (1972), “The Statistical Theory of Racism and Sexism”, American Economic Review, Vol. 62, No. 4, pp 659-661.

Riach et Rich (1991), “Testing for Racial Discrimination in the Labour Market”, Cambridge Journal of Economics, vol 15, p239-256. 
Richard J.-L. (2006) "Présomption de discrimination à l'encontre des enfants d'immigré(s) africain(s)”, Migrations Société, vol. 18, No. 105-106, May-August.

Silberman, R et Fournier, I (2006), “Jeunes issus de l’immigration : une pénalité à l'embauche qui perdure”, Bref du CEREQ, No. 226.

Silverman B. (1986). Density Estimation for Statistics and Data Analysis. Chapman \& Hall. ISBN 0412246201.

Taran P. (2005). « Immigration, discrimination and integration in Europe : Policy options for Europe in the 21st century ». Note, International Labor Organization.

Viprey M. (2002), “Les mécanismes de discrimination à l'égard des jeunes dont l'origine étrangère est réelle ou supposée”, Revue de l'IRES, No. 39, 2002/2. 
Appendix A : Jackknife estimates of the standard errors

Table A.1 : Effects of nationality, name and forename on matched job applications

Comparisons are made on the same job offers. Several applications are sent to each job offers. The number of applications can vary from one job to another due to "preselection" by the ANPE **: significant at $5 \%$; *: significant at $10 \%$

\begin{tabular}{|c|c|c|c|c|c|c|}
\hline \multirow[t]{2}{*}{ Difference $^{1}$} & \multirow[t]{2}{*}{ Effect measured } & \multirow[t]{2}{*}{ Total sample } & \multicolumn{2}{|c|}{ Qualification } & \multicolumn{2}{|c|}{ Type of city } \\
\hline & & & Low (Baccalauréat) & High (BTS) & Underprivileged & Privileged \\
\hline FMM-MMM & Number of jobs offers/Number of CVs & $138 / 541$ & $62 / 242$ & $76 / 299$ & $135 / 270$ & $133 / 266$ \\
\hline \multirow[t]{2}{*}{ Nationality } & Difference in success rates & $1.45 \%$ & $0.81 \%$ & $1.97 \%$ & $1.48 \%$ & $1.50 \%$ \\
\hline & Jackknife Student T & $1.64^{\star}$ & 1.00 & 1.35 & 1.00 & 1.42 \\
\hline FMF-MMM & Number of jobs offers/Number of CVs & $138 / 545$ & $62 / 245$ & $76 / 300$ & $136 / 272$ & $134 / 268$ \\
\hline \multirow{2}{*}{$\begin{array}{l}\text { Nationality and } \\
\text { forename }\end{array}$} & Difference in success rates & $2.54 \%$ & $1.61 \%$ & $3.29 \%$ & $2.21 \%$ & $2.99 \%$ \\
\hline & Jackknife Student T & $2.37^{\star \star}$ & 1.43 & $1.92^{\star}$ & 1.35 & $2.02^{\star \star}$ \\
\hline FFF-MMM & Number of jobs offers/Number of CVs & $137 / 542$ & $62 / 245$ & $75 / 297$ & $134 / 268$ & $134 / 268$ \\
\hline \multirow{2}{*}{$\begin{array}{l}\text { Nationality, name } \\
\text { and forename }\end{array}$} & Difference in success rates & $6.93 \%$ & $4.84 \%$ & $8.67 \%$ & $5.22 \%$ & $8.96 \%$ \\
\hline & Jackknife Student T & $3.44^{\star \star}$ & $1.94^{\star}$ & $2.84^{\star \star}$ & $2.37^{\star \star}$ & $3.62^{\star \star}$ \\
\hline FMF-FMM & Number of jobs offers/Number of CVs & $139 / 546$ & $61 / 240$ & $78 / 306$ & $135 / 270$ & $134 / 268$ \\
\hline \multirow{2}{*}{ Forename } & Difference in success rates & $1.08 \%$ & $0.82 \%$ & $1.28 \%$ & $0.74 \%$ & $1.49 \%$ \\
\hline & Jackknife Student T & 1.14 & 1.00 & 0.81 & 1.16 & 0.82 \\
\hline FFF-FMM & Number of jobs offers/Number of CVs & $138 / 544$ & $62 / 243$ & 76/301 & $133 / 266$ & $135 / 270$ \\
\hline \multirow{2}{*}{$\begin{array}{l}\text { Name and } \\
\text { forename }\end{array}$} & Difference in success rates & $5.43 \%$ & $4.03 \%$ & $6.58 \%$ & $3.01 \%$ & $7.41 \%$ \\
\hline & Jackknife Student T & $2.97^{\star \star}$ & $1.69^{\star}$ & $2.43^{\star \star}$ & 1.27 & $2.97^{\star \star}$ \\
\hline FFF-FMF & Number of jobs offers/Number of CVs & $137 / 546$ & $61 / 243$ & $76 / 303$ & $136 / 272$ & $136 / 272$ \\
\hline \multirow[t]{2}{*}{ Name } & Difference in success rates & $4.38 \%$ & $3.28 \%$ & $5.26 \%$ & $2.94 \%$ & $5.88 \%$ \\
\hline & Jackknife Student T & $2.50^{\star \star}$ & $1.66^{\star}$ & $1.92^{\star}$ & 1.16 & $2.58^{\star \star}$ \\
\hline
\end{tabular}

1. MMM: Moroccan nationality, name and forename. FMM: French nationality, Moroccan name and forename. FMF: French nationality, Moroccan name and French forename. FFF: French nationality, name and forename. 


\section{Appendix B : Application of the bootstrap}

Two important points, closely related, must be examined when computing the bootstrapped standard errors :

- $\quad$ the computation of the number of drawings;

- the check of the eigenvalues of the cross products of the right-hand variables for each bootstrapped sample.

This two points are related for the following reason. When there are many dummy variables with some including a small number of positive responses, it is possible that, on some samples, the right hand variables exhibit near multicolinearity. This problem will tend to generate extreme values for the parameter estimates, affect their variance and, as a consequence, the formula for the optimal number of drawings.

Consider first the optimal number of drawings. It is determined according to Andrews and Buchinsky (2000). The idea is to set the number of drawings (B) according to the following constraint :

$$
P\left[100 \frac{\left|\hat{\sigma}_{B}-\hat{\sigma}_{\infty}\right|}{\hat{\sigma}_{\infty}} \leq p d b\right]=1-\tau
$$

where $\hat{\sigma}_{B}$ is the bootstrapped standard error and $\hat{\sigma}_{\infty}$ the "ideal" bootstrapped standard error that would have been obtained with an infinite number of drawing. In this paper, we have set $p d b=5$ and $\tau=0,05$, that is we impose that our estimate should not depart from more than $5 \%$ of the ideal estimate with probability 95\%. The three-step method is as follows :

- $\quad$ Step 1 : Compute a first number of drawings : $B_{1}=\operatorname{int}\left(5000 \times 3,84 / p d b^{2}\right)=768$;

- Step 2 : Simulate $B_{1}=768$ bootstrap samples and compute $\hat{\gamma}_{2}$, the estimated Fisher kurtosis coefficient :

$$
\hat{\gamma}_{2}=\left(\frac{1}{B_{1}-1} \sum_{j=1}^{B_{1}}\left(\hat{\sigma}_{j}-\frac{1}{B_{1}} \sum_{k=1}^{B_{1}} \hat{\sigma}_{k}\right)^{4}\right) /\left(\frac{1}{B_{1}-1} \sum_{j=1}^{B_{1}}\left(\hat{\sigma}_{j}-\frac{1}{B_{1}} \sum_{k=1}^{B_{1}} \hat{\sigma}_{k}\right)^{2}\right)^{2}-3
$$

- $\quad$ Step 3 : Simulate $\max \left(0, B_{2}-B_{1}\right)$ additional bootstrap samples with :

$$
B_{2}=\operatorname{int}\left(2500 \times 3,84 \times\left(2+\hat{\gamma}_{2}\right) / p d b^{2}\right)
$$

- Since there is one variance estimate corresponding to each OLS parameter, we take the maximum number of drawings over all the parameters. In Table 12, this number is denoted $B=\max \left(B_{1}, B_{2}\right)$.

Consider now the near multicolinearity problem. The previous optimal number of drawings is obviously sensitive to the presence of outliers in the bootstrapped estimates. This is why we have 
put a special care examining the near multicolinearity properties of the bootstrap samples. We have applied the following method :

- Step 1 : Use the $B_{1}=768$ first-step bootstrap samples and compute the lowest eigenvalue of each of the right-hand variables cross-products matrix;

- Step 2 : Draw the density of the lowest eigenvalues and define a cutoff point. The kernel density estimate is given by Figure 1 . On the basis of this density, we have set the minimal eigenvalue at 0,0024 . This value defines an admissible bootstrap sample;

- Step 3 : Apply the Andrews and Buchinsky method (Steps 1 to 3) to the samples that respect the eigenvalue condition. In practice, an additional loop is added inside the bootstrap estimation program so that $B$ represents the number of admissible bootstrap samples.

\section{Figure B.1 : Density of the minimum eigenvalue of the first-step bootstrap samples (before correction)}

Kernel density estimator with an Epanechnikov kernel and a Silverman (1986) optimal window

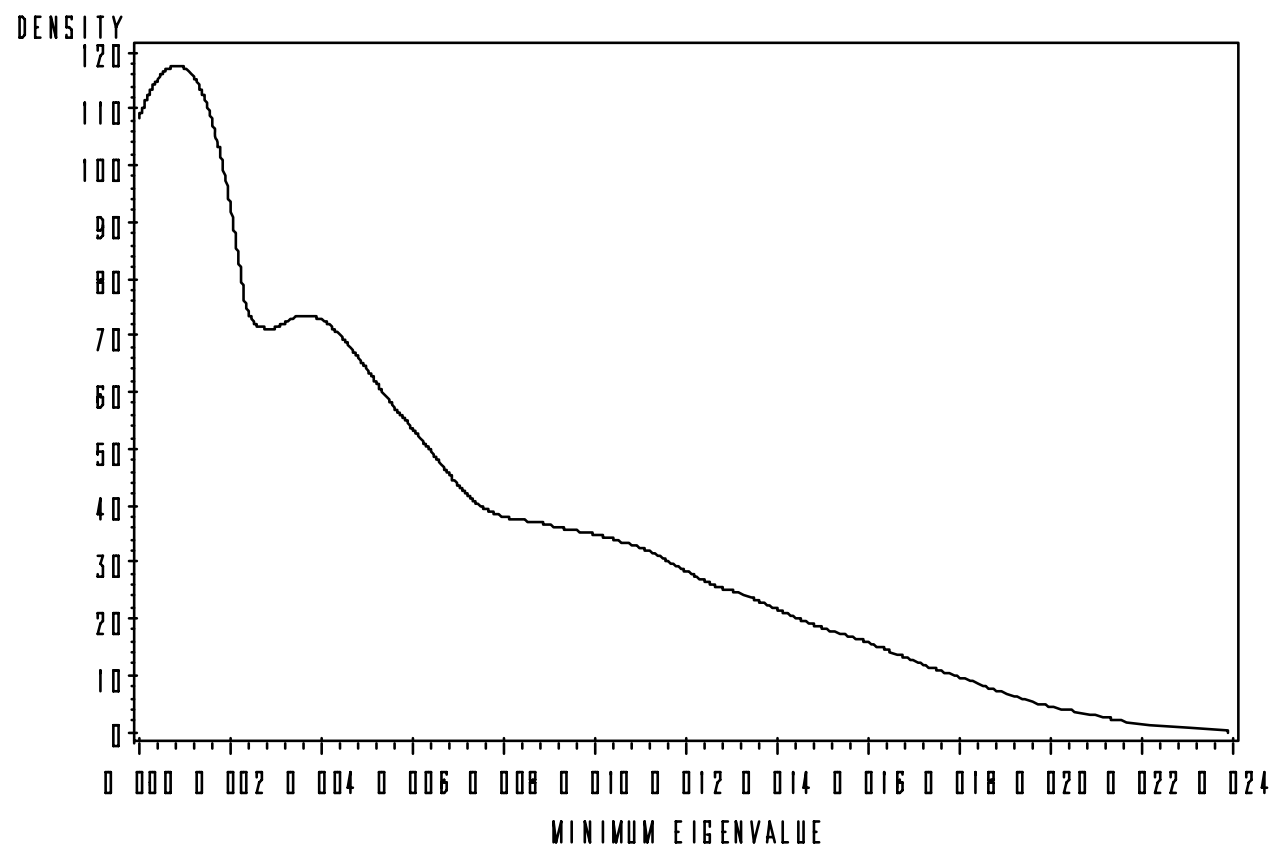




\section{Appendix C : Suitability of the linear model}

Insofar as the difference between two ratios is used as the left-hand variable, it is easy to justify a linear model because the left-hand variable is continuous. However, since the explained variable is limited to the range $[-1,+1]$, it is often requested that it be verified that the predictions of the model do indeed lie within that range. Table C-1 shows that this is indeed the case, and Graph C-1 shows that the distribution of the predictions does indeed have the profile of a continuous variable.

Table C-1: Admissibility of the OLS predictions

All of the predictions of the model belong to the range $]-1,+1[$. The model can thus be estimated by the ordinary least squares.

\begin{tabular}{ll}
\hline \hline Statistic & Value \\
\hline Minimum & -0.120 \\
First quartile & 0.014 \\
Median & 0.047 \\
Third quartile & 0.104 \\
Maximum & 0.229 \\
\hline Mean & 0.056 \\
Standard deviation & 0.070 \\
Standard deviation of the mean & 0.006 \\
\hline \hline
\end{tabular}

Graph C-1: Distribution of predictions

(after progressive elimination at the threshold of 10\%)

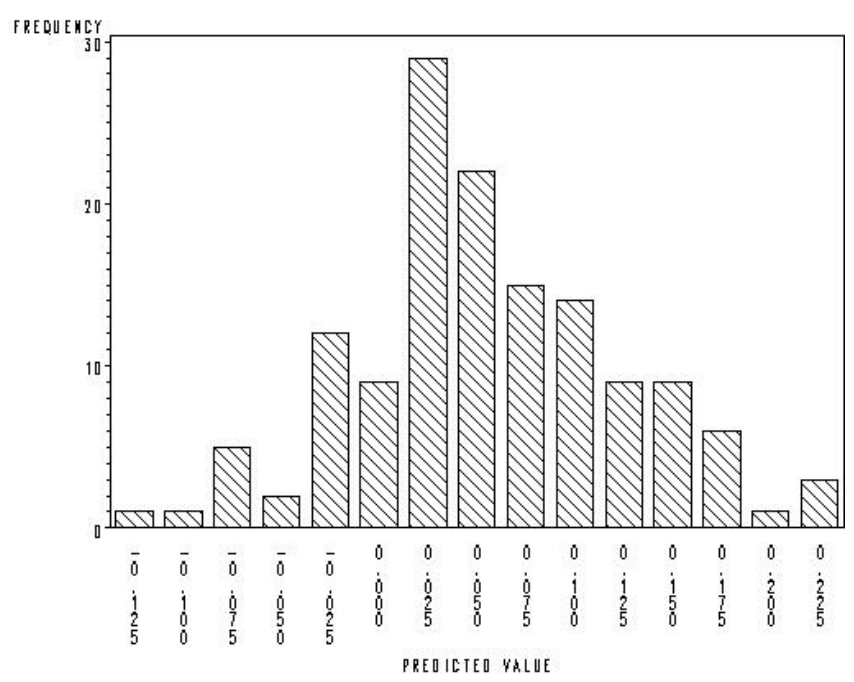




\section{Appendix D : Alternative computations of regression standard errors}

This appendix includes the OLS standard errors and the White heteroskedasticity-robust standard errors. We find that the OLS standard errors lead to a misleading significance level for the Cubitus stamp dummy. It appears significant while it is not according to the bootstrapped and White standard errors.

Table D.1: Backward elimination procedure based on the OLS standard errors

Student $t$ statistics are computed from the OLS standard errors. ** : significant at $5 \%$ * : significant at $10 \%$

\begin{tabular}{|c|c|c|c|c|c|c|c|c|c|c|c|c|c|c|c|c|}
\hline \multirow[t]{2}{*}{ Regression } & \multirow[t]{2}{*}{ Statistic } & $\begin{array}{c}\text { Mean } \\
\text { discrimination } \\
\text { coefficient }\end{array}$ & $\begin{array}{l}\text { Residence } \\
\text { in an } \\
\text { under- } \\
\text { privileged } \\
\text { city/FFF }\end{array}$ & $\begin{array}{l}\text { Cubitus } \\
\text { Stamp } \\
\text { /FFF }\end{array}$ & $\begin{array}{c}\text { Pre- } \\
\text { stamped } \\
\text { letter / } \\
\text { FFF }\end{array}$ & $\begin{array}{l}\text { Commur } \\
\text { ting time } \\
\text { /FFF }\end{array}$ & $\begin{array}{l}\text { Residence } \\
\text { in an } \\
\text { under- } \\
\text { privileged } \\
\text { city }\end{array}$ & $\begin{array}{l}\text { Cubitus } \\
\text { Stamp }\end{array}$ & $\begin{array}{c}\text { Pre- } \\
\text { stamped } \\
\text { letter }\end{array}$ & $\begin{array}{l}\text { Commu- } \\
\text { ting time }\end{array}$ & $\begin{array}{l}\text { Use of } \\
\text { Email }\end{array}$ & $\begin{array}{l}\text { Indefinite } \\
\text { term } \\
\text { contract }\end{array}$ & $\begin{array}{l}\text { Subsidiary } \\
\text { of a large } \\
\text { corporation }\end{array}$ & $\begin{array}{l}\text { Through } \\
\text { the } \\
\text { ANPE }\end{array}$ & $\begin{array}{c}\text { Resume } \\
\text { template } \\
\text { No. } 2\end{array}$ & $\begin{array}{c}\text { Job locatec } \\
\text { in Paris } \\
\text { itself }\end{array}$ \\
\hline & & Intercept & \multicolumn{4}{|c|}{ Variables in differences } & \multicolumn{10}{|c|}{ Variables in levels } \\
\hline \multirow{2}{*}{1} & Coeff & 0,056 & $-0,260$ & $-0,343$ & 0,793 & $-0,004$ & 0,482 & 0,750 & $-1,073$ & 0,002 & $-0,211$ & $-0,059$ & $-0,081$ & $-0,109$ & $-0,049$ & 0,054 \\
\hline & Student & $3,254^{\star \star}$ & 0,344 & 0,625 & 1,087 & 1,642 & 0,371 & 0,999 & 1,045 & 0,516 & 0,815 & 1,601 & $1,924^{\star}$ & $2,301^{\star \star}$ & 0,804 & 1,226 \\
\hline \multirow{2}{*}{2} & Coeff & 0,056 & & $-0,372$ & 0,658 & $-0,004$ & 0,049 & 0,794 & $-0,888$ & 0,002 & $-0,163$ & $-0,060$ & $-0,079$ & $-0,107$ & $-0,053$ & 0,055 \\
\hline & Student & $3,266^{\star *}$ & & 0,687 & 1,075 & 1,618 & 0,153 & 1,077 & 1,019 & 0,509 & 0,750 & 1,619 & $1,907^{\star}$ & $2,284^{\star \star}$ & 0,917 & 1,256 \\
\hline \multirow{2}{*}{3} & Coeff & 0,056 & & $-0,351$ & 0,662 & $-0,004$ & & 0,768 & $-0,890$ & 0,002 & $-0,165$ & $-0,060$ & $-0,080$ & $-0,107$ & $-0,051$ & 0,055 \\
\hline & Student & $3,279^{\star \star}$ & & 0,673 & 1,088 & 1,626 & & 1,075 & 1,026 & 0,516 & 0,763 & 1,628 & $1,934^{\star}$ & $2,309^{\star *}$ & 0,912 & 1,260 \\
\hline \multirow{2}{*}{4} & Coeff & 0,056 & & $-0,347$ & 0,670 & $-0,003$ & & 0,753 & $-0,907$ & & $-0,166$ & $-0,061$ & $-0,079$ & $-0,107$ & $-0,051$ & 0,042 \\
\hline & Student & $3,288^{\star \star}$ & & 0,667 & 1,104 & $1,871^{*}$ & & 1,058 & 1,049 & & 0,772 & 1,660 & $1,922^{\star}$ & $2,306^{\star \star}$ & 0,917 & 1,175 \\
\hline \multirow{2}{*}{5} & Coeff & 0,056 & & & 0,565 & $-0,003$ & & 0,290 & $-0,758$ & & $-0,192$ & $-0,063$ & $-0,077$ & $-0,106$ & $-0,053$ & 0,040 \\
\hline & Student & $3,296^{\star \star}$ & & & 0,967 & $1,823^{\star}$ & & $1,892^{\star}$ & 0,909 & & 0,908 & $1,724^{\star}$ & $1,873^{\star}$ & $2,285^{\star \star}$ & 0,950 & 1,113 \\
\hline \multirow{2}{*}{6} & Coeff & 0,056 & & & 0,054 & $-0,003$ & & 0,338 & $-0,023$ & & & $-0,060$ & $-0,085$ & $-0,099$ & $-0,045$ & 0,043 \\
\hline & Student & $3,298^{\star \star}$ & & & 0,345 & $1,835^{\star}$ & & $2,360^{\star \star}$ & 0,115 & & & $1,647^{\star}$ & $2,152^{\star \star}$ & $2,174^{\star \star}$ & 0,816 & 1,211 \\
\hline \multirow{2}{*}{7} & Coeff & 0,056 & & & 0,038 & $-0,003$ & & 0,336 & & & & $-0,060$ & $-0,085$ & $-0,099$ & $-0,049$ & 0,043 \\
\hline & Student & $3,311^{\star \star}$ & & & 0,491 & $1,845^{\star}$ & & $2,373^{\star \star}$ & & & & $1,654^{\star}$ & $2,158^{\star \star}$ & $2,193^{\star \star}$ & 1,182 & 1,212 \\
\hline \multirow{2}{*}{8} & Coeff & 0,056 & & & & $-0,003$ & & 0,325 & & & & $-0,060$ & $-0,085$ & $-0,098$ & $-0,051$ & 0,042 \\
\hline & Student & $3,320^{\star \star}$ & & & & $1,845^{\star}$ & & $2,331^{\star \star}$ & & & & $1,671^{\star}$ & $2,148^{\star \star}$ & $2,169^{\star \star}$ & 1,231 & 1,189 \\
\hline \multirow{2}{*}{9} & Coeff & 0,056 & & & & $-0,003$ & & 0,317 & & & & $-0,058$ & $-0,086$ & $-0,101$ & $-0,055$ & \\
\hline & Student & $3,315^{\star \star}$ & & & & $2,044^{\star \star}$ & & $2,275^{\star \star}$ & & & & 1,618 & $2,194^{\star \star}$ & $2,232^{\star \star}$ & 1,338 & \\
\hline \multirow{2}{*}{10} & Coeff & 0,056 & & & & $-0,003$ & & 0,252 & & & & $-0,064$ & $-0,090$ & $-0,106$ & & \\
\hline & Student & $3,305^{\star \star}$ & & & & $1,965^{\star \star}$ & & $1,924^{\star}$ & & & & $1,794^{\star}$ & $2,272^{\star \star}$ & $2,350^{\star \star}$ & & \\
\hline
\end{tabular}


Table D.2: Backward elimination procedure based on the White's standard errors

Student $t$ statistics are computed from the White (1980) heteroskedasticity robust standard errors. ** : significant at $5 \%$ * : significant at $10 \%$

\begin{tabular}{|c|c|c|c|c|c|c|c|c|c|c|c|c|c|c|c|c|}
\hline \multirow[t]{2}{*}{ Regression } & \multirow[t]{2}{*}{ Statistic } & $\begin{array}{c}\text { Mean } \\
\text { discrimination } \\
\text { coefficient }\end{array}$ & $\begin{array}{l}\text { Residence } \\
\text { in an } \\
\text { under- } \\
\text { privileged } \\
\text { city/FFF }\end{array}$ & $\begin{array}{l}\text { Cubitus } \\
\text { Stamp } \\
\text { /FFF }\end{array}$ & $\begin{array}{c}\text { Pre- } \\
\text { stamped } \\
\text { letter / } \\
\text { FFF }\end{array}$ & $\begin{array}{l}\text { Commu- } \\
\text { ting time } \\
\text { /FFF }\end{array}$ & $\begin{array}{l}\text { Residence } \\
\text { in an } \\
\text { under- } \\
\text { privileged } \\
\text { city }\end{array}$ & $\begin{array}{l}\text { Cubitus } \\
\text { Stamp }\end{array}$ & $\begin{array}{c}\text { Pre- } \\
\text { stamped } \\
\text { letter }\end{array}$ & $\begin{array}{l}\text { Commu- } \\
\text { ting time }\end{array}$ & $\begin{array}{l}\text { Use of } \\
\text { Email }\end{array}$ & $\begin{array}{c}\text { Indefinite } \\
\text { term } \\
\text { contract }\end{array}$ & $\begin{array}{l}\text { Subsidiary } \\
\text { of a large } \\
\text { corporation }\end{array}$ & $\begin{array}{l}\text { Through } \\
\text { the } \\
\text { ANPE }\end{array}$ & $\begin{array}{c}\text { Resume } \\
\text { template } \\
\text { No. } 2\end{array}$ & $\begin{array}{c}\text { Job locatec } \\
\text { in Paris } \\
\text { itself }\end{array}$ \\
\hline & & Intercept & \multicolumn{4}{|c|}{ Variables in differences } & \multicolumn{10}{|c|}{ Variables in levels } \\
\hline \multirow{2}{*}{1} & Coeff & 0,056 & $-0,260$ & $-0,343$ & 0,793 & $-0,004$ & 0,482 & 0,750 & $-1,073$ & 0,002 & $-0,211$ & $-0,059$ & $-0,081$ & $-0,109$ & $-0,049$ & 0,054 \\
\hline & Student & $3,447^{\star \star}$ & 0,335 & $1,881^{*}$ & 0,958 & $1,824^{\star}$ & 0,376 & $2,408^{\star *}$ & 0,968 & 0,816 & 0,732 & $1,698^{\star}$ & $2,466^{\star *}$ & $2,072^{\star \star}$ & 0,743 & 1,380 \\
\hline \multirow{2}{*}{2} & Coeff & 0,056 & & $-0,372$ & 0,658 & $-0,004$ & 0,049 & 0,794 & $-0,888$ & 0,002 & $-0,163$ & $-0,060$ & $-0,079$ & $-0,107$ & $-0,053$ & 0,055 \\
\hline & Student & $3,445^{\star \star}$ & & $1,716^{\star}$ & 1,137 & $1,801^{*}$ & 0,303 & $2,185^{\star \star}$ & 1,143 & 0,807 & 0,787 & $1,723^{\star}$ & $2,394^{\star \star}$ & $2,062^{\star \star}$ & 0,817 & 1,382 \\
\hline \multirow{2}{*}{3} & Coeff & 0,056 & & $-0,351$ & 0,662 & $-0,004$ & & 0,768 & $-0,890$ & 0,002 & $-0,165$ & $-0,060$ & $-0,080$ & $-0,107$ & $-0,051$ & 0,055 \\
\hline & Student & $3,445^{\star \star}$ & & 1,527 & 1,143 & $1,802^{*}$ & & $1,960^{\star *}$ & 1,144 & 0,813 & 0,783 & $1,719^{\star}$ & $2,422^{\star *}$ & $2,078^{\star \star}$ & 0,861 & 1,379 \\
\hline \multirow{2}{*}{4} & Coeff & 0,056 & & $-0,423$ & 0,259 & $-0,004$ & & 0,904 & $-0,310$ & 0,002 & & $-0,057$ & $-0,088$ & $-0,102$ & $-0,044$ & 0,058 \\
\hline & Student & $3,437^{\star \star}$ & & $1,723^{\star}$ & 0,999 & $1,790^{\star}$ & & $2,028^{\star \star}$ & 1,091 & 0,820 & & $1,661^{*}$ & $2,774^{\star \star}$ & $1,958^{\star \star}$ & 0,837 & 1,470 \\
\hline \multirow{2}{*}{5} & Coeff & 0,056 & & $-0,419$ & 0,263 & $-0,003$ & & 0,890 & $-0,321$ & & & $-0,058$ & $-0,087$ & $-0,102$ & $-0,044$ & 0,045 \\
\hline & Student & $3,433^{\star \star}$ & & $1,696^{*}$ & 1,010 & $2,066^{\star \star}$ & & $1,990^{\star \star}$ & 1,125 & & & $1,695^{\star}$ & $2,733^{\star \star}$ & $1,945^{\star \star}$ & 0,837 & 1,138 \\
\hline \multirow{2}{*}{6} & Coeff & 0,056 & & $-0,426$ & 0,341 & $-0,003$ & & 0,880 & $-0,429$ & & & $-0,061$ & $-0,089$ & $-0,103$ & & 0,048 \\
\hline & Student & $3,425^{\star *}$ & & $1,627^{*}$ & 1,422 & $2,030^{\star \star}$ & & $1,894^{\star}$ & $1,723^{\star}$ & & & $1,730^{\star}$ & $2,772^{\star \star}$ & $1,993^{\star \star}$ & & 1,234 \\
\hline \multirow{2}{*}{7} & Coeff & 0,056 & & $-0,366$ & 0,310 & $-0,003$ & & 0,786 & $-0,393$ & & & $-0,059$ & $-0,091$ & $-0,106$ & & \\
\hline & Student & $3,400^{\star \star}$ & & 1,411 & 1,309 & $2,297^{\star \star}$ & & $1,711^{*}$ & 1,618 & & & $1,687^{\star}$ & $2,783^{\star \star}$ & $2,019^{\star \star}$ & & \\
\hline \multirow{2}{*}{8} & Coeff & 0,056 & & 0,135 & & $-0,003$ & & 0,103 & 0,020 & & & $-0,063$ & $-0,089$ & $-0,103$ & & \\
\hline & Student & $3,384^{\star \star}$ & & 0,635 & & $2,200^{\star *}$ & & 0,366 & 0,198 & & & $1,840^{*}$ & $2,699^{\star *}$ & $1,948^{\star}$ & & \\
\hline \multirow{2}{*}{9} & Coeff & 0,056 & & 0,114 & & $-0,003$ & & 0,128 & & & & $-0,063$ & $-0,089$ & $-0,103$ & & \\
\hline & Student & $3,384^{\star \star}$ & & 0,787 & & $2,198^{\star \star}$ & & 0,494 & & & & $1,845^{\star}$ & $2,693^{\star \star}$ & $1,910^{\star}$ & & \\
\hline \multirow{2}{*}{10} & Coeff & 0,056 & & 0,198 & & $-0,003$ & & & & & & $-0,063$ & $-0,088$ & $-0,105$ & & \\
\hline & Student & $3,381^{\star \star}$ & & 1,540 & & $2,140^{\star \star x}$ & & & & & & $1,842^{\star}$ & $2,694^{\star \star}$ & $2,009^{\star \star}$ & & \\
\hline \multirow{2}{*}{11} & Coeff & 0,056 & & & & $-0,002$ & & & & & & $-0,070$ & $-0,089$ & $-0,138$ & & \\
\hline & Student & $3,333^{\star \star}$ & & & & $1,842^{\star}$ & & & & & & $1,904^{\star}$ & $2,734^{\star \star}$ & $2,707^{\star \star}$ & & \\
\hline
\end{tabular}



10-1. Are young French jobseekers of ethnic immigrant origin discriminated against? A controlled experiment in the Paris area

Emmanuel Duguet, Noam Leandri, Yannick L'Horty, Pascale Petit

10-2. Couple's Work Hours, Satisfaction and reconciling Work and family Life

Nathalie Georges, Dominique Méda, Danièle Trancart

10-3. Housing ownership, social housing and unemployment: an econometric analysis of the Paris area

Emmanuel Duguet, Yannick L'Horty, Florent Sari

10-4. Do Public Subsidies Have an Impact on New Firm Survival? An Empirical Study with French Data

Lionel Désiage, Richard Duhautois, Dominique Redor

10-5. The effect of social security payroll tax reductions on employment and wages: an evaluation of the 2003 French reform

Matthieu Bunel, Fabrice Gilles, Yannick L'Horty

10-6. What are Entrepreneurs' Objectives When Starting a New Business?

Lionel Désiage

10-7. Health and Early Retirement: Evidence from French Data for individuals

Thomas Barnay, Karine Briard

10-8. Ageing, chronic conditions and the evolution of future drugs expenditures Thomas Barnay, Sophie Thiébaut, Bruno Ventelou

10-9. Entrepreneurial motives and performance: Why might better educated entrepreneurs be less successful?

Arnab Bhattacharjee, Jean Bonnet, Nicolas Le Pape, Régis Renault

10-10. Returns to firm-provided training in France: Evidence on mobility and wages Arnaud Chéron, Bénédicte Rouland, François-Charles Wolff

10-11. Taxation of early retirement windows and delaying retirement: the French experience

Pierre-Jean Messe 
10-12. Pre Entry Motives into Entrepreneurship and Post Entry Entrepreneurial Orientation

Jean Bonnet, Nicolas Le Pape

10-13. Hiring Practices, Employment Protection and Temporary Jobs

Anne Bucher

10-14. Young-in Old-out: a new evaluation

Michela Bia, Pierre-Jean Messe, Roberto Leombruni

10-15. On the impact of the TFP growth on the employment rate: does training on-thejob matter?

Eva Moreno-Galbis

10-16. The dynamics of youth labor market integration

Anne Bucher

10-17. Fostering the potential endogenous development of European regions: a spatial dynamic panel data analysis of the Cohesion Policy on regional convergence over the period 1980-2005

Salima Bouayad-Agha, Nadine Turpin, Lionel Védrine

10-18. Cost-saving or Cost-enhancing Mergers: the Impact of the Distribution of Roles in Oligopoly

Nicolas Le Pape, Kai Zhao

10-19. Bankruptcy Risk, Product Market Competition and Horizontal Mergers

Bernard Franck, Nicolas Le Pape

10-20. Endogenous Job Destructions and the Distribution of Wages

Arnaud Chéron, Bénédicte Rouland

10-21. Employment Protection Legislation and Adverse Selection at the Labor Market Entry

Anne Bucher, Sébastien Ménard 
The CNRS Institute for Labor Studies and Public Policies (the TEPP Institute, FR $n^{\circ} 3126$ CNRS) gathers together research centres specializing in economics and sociology:

- the Centre d'Etudes de I'Emploi (Centre for Employment Studies), CEE, Public Administrative Organization, under the leadership of the Ministers of Work and Research

- l'Equipe de Recherche sur les Marchés, l'Emploi et la Simulation (Research Team on Markets, Employment and Simulation), ERMES, University of Paris II PanthéonAssas

- the Centre d'Etudes des Politiques Economiques de l'université d'Evry (Research Centre focused on the analysis of economic policy and its foundations and implications), EPEE, University of Evry Val d'Essonne

- the Centre Pierre Naville (Research on Work and Urban Policies), CPN, University of Evry Val d'Essonne

- l'Equipe de Recherche sur l'Utilisation des Données Temporelles en Economie (Research Team on Use of Time Data in Economics), ERUDITE, University of ParisEst Créteil and University of Paris-Est Marne-la-Vallée

- the Groupe d'Analyse des Itinéraires et des Niveaux Salariaux (The Group on Analysis of Wage Levels and Trajectories), GAINS, University of the Maine

The TEPP Institute brings together 115 researchers and research professors, $140 \mathrm{PhD}$ students and 40 associate researchers who study changes in work and employment in relation to the choices made by firms and analyse public policies using new evaluation methods. 